\title{
Infections and Acute Leukemia in Children with Down Syndrome
}

\author{
Juan Manuel Mejía-Aranguré et al.* \\ Unidad de Investigación Médica en Epidemiología Clínica, Hospital de Pediatría, \\ Instituto Mexicano del Seguro Social (IMSS). \\ División de Laboratorios de Vigilancia e Investigación Epidemiológica, IMSS.
}

Mexico

\section{Introduction}

Down syndrome (DS), or trisomy 21, is a genetic alteration caused by the presence of an extra chromosome 21. In different parts of the world, the incidence of DS varies from 0.3 to 3.4 per 1000 births, with a ratio of 1:1000 births being reported principally in America and Europe (Canfield et al., 2006; Hassold et al., 1996; Wahab et al., 2006; Webb et al., 2007). DS is associated with cardiovascular diseases; deficiencies of the digestive, immune, and endocrine systems; hematological problems; and also early onset of Alzheimer disease (Freeman et al., 2008; Holland et al., 2000; Linabery et al., 2008; Van Cleeve \& Cohen, 2006; Wiseman et al., 2009).

Compared to children without this syndrome, children with DS have ten- to twenty-fold higher risk of developing acute leukemia (AL) (Fong \& Brodeur, 1987; Malinge et al., 2009; Ross et al., 2005a; Taub, 2001); it is estimated that approximately 1-2\% will develop leukemia (Hasle et al., 2000; Malinge et al., 2009; Taub, 2001). Of those children with DS who develop leukemia, $60 \%$ is classified as having acute lymphoblastic leukemia (ALL) and 40\%, with acute myeloblastic leukemia (AML). Of those with AML, the most common type is M7, or acute megakaryoblastic leukemia (AMKL), found in $62 \%$ of this group of children (Hitzler \& Zipursky, 2005). Approximately 10\% of children with DS are born with a transitory myeloproliferative syndrome (TMS) that, in some cases, spontaneously disappears during the first few months of life; nevertheless, approximately, $20 \%$ of these children irreversibly develop AML. Children with DS have up to 500-fold higher risk of developing AMKL during the first four years (Hasle et al., 2000, 2001; Malinge et al., 2009; Zipursky, 2003).

Because the high incidence of AL in children with DS is strong evidence of the participation of chromosome 21 in the development of $\mathrm{AL}$, investigation has been directed toward the

\footnotetext{
*María Luisa Pérez-Saldivar, Janet Flores-Lujano, Carolina Bekker Méndez, Sandra Pinto-Cardoso, David Aldebarán Duarte-Rodríguez, Arturo Fajardo-Gutiérrez

Unidad de Investigación Médica en Epidemiología Clínica, Hospital de Pediatría, Instituto Mexicano del Seguro Social (IMSS).

División de Laboratorios de Vigilancia e Investigación Epidemiológica, IMSS.Mexico

Histocompatibility \& Immunogenetics (HEI) laboratory,

National Health Service Blood and Transplant (NHSBT)UK
} 
search for a gene, or genes, on chromosome 21 which may cause an interruption of cellular differentiation and mark the onset of AL. Research has been focused specifically on the study of the relation that exists between TMS and its developing into AMKL in patients with DS (Gamis \& Hilden, 2002; Roy et al., 2009; Taub \& Ravindranath, 2002; Zwaan et al., 2010). Study of this model has permitted the identification of the genes that provoke mutations that cooperate in the malignant transformation of hematopoietic precursor cells. One of these genes is GATA1 (Hitzler et al., 2003; Vyas \& Roberts, 2006; Zwaan et al., 2010), which codes for a transcription factor of chromosome $X$ which codes for the signaling of zinc which is essential for the differentiation of erythrocytes and magakaryocytes in the hematopoietic cell line. Mutation in this gene causes the production of the short protein, GATA1s, having an altered capacity of transactivation, thus contributing to the uncontrolled proliferation of immature megakaryocytes (Cantor, 2005; Hitzler et al., 2003; Wechsler et al., 2002). It has been found that mutation occurs in utero and, therefore, acts as an early pathological event, prior to the onset of TMS; however, in the absence of trisomy 21, such mutation is not sufficient for the induction of leukemia. Another transcription factor RUNX1, encoded by a gene on chromosome 21, plays a very important role in the development of AML (Hitzler \& Zipursky, 2005; Izraeli et al., 2007). RUNX1 is essential for the differentiation of megakaryocyte progenitors and is responsible for the reduction of platelets (Migas et al., 2011; Speck \& Gilliland, 2002). The function of RUNX1 is commonly interrupted by chromosomal translocations that have been associated with different types of AL. These include the translocation $\mathrm{t}(8 ; 21)$ that generates the fusion gene RUNX1/CBFA2T1 or AML1/ETO, which is associated with $40 \%$ of the AML type M2; the translocation $\mathrm{t}(12 ; 21)$, called fusion gene ETV6/RUNX1 or TEL/AML1, which is associated with $20 \%$ of ALL of the pro-B-cell precursors; and the gene that codes for $\mathrm{CBF} \beta$ and that is the target of chromosomal aberrations such as inv(16) and t(16;16) in AML type M4 (Karrman et al., 2006; Zuna et al., 2011). Although it had been thought that GATA1 and RUNX1 were exclusive, it was later shown that RUNX1 cooperates with GATA1 during megakaryocytic differentiation, playing a very important role in predisposing a patient with DS to develop AMKL (Elagib et al., 2003). Nevertheless, in a recent study by the Children's Oncological Group (COG), it was found that children with DS had significantly fewer ETV6/RUNX1 abnormalities than did children without DS (Maloney et al., 2010). Other genes that undergo mutations are Janus Kinase 2 (JAK2) and Janus Kinase 3 (JAK3) (Malinge et al., 2009); these genes are located on chromosome 9p24 and activate the encoding of tyrosine kinase, which has been reported in the majority of patients with myeloproliferative disorders. This type of mutation brings about a dysregulation of the activity of the kinase and a phosphorylation of tyrosine (Meydan et al., 1996; Mullighan et al., 2009). However, it has been shown that patients with DS who have this mutation have a better response to chemotherapeutic treatment. Other potential candidates include the transcription factors of the family of protooncogenes, such as ETS, ERG, and GABPa, which have been shown to be expressed and to functionally participate in megakaryocytic differentiation (Wiseman et al., 2009). The dysregulation of the proto-oncogene EGR has been observed in different types of cancer; $E G R$ is over-expressed in AML, just as the proto-oncogene ETS2 is over-expressed in AMKL; this dysregulation directly affects the cell cycle by regulating the expression of genes that require DNA synthesis and the degradation of the inhibitors of the cell cycle. It appears to a critical regulator of the development of lymphocytes in the precursors of B cells (Holterman et al., 2010; Sashida et al., 2010).

From the foregoing and from other reports in the literature, the mechanisms that predispose children with DS to develop AL are augmented by chromosome fragility, alteration of DNA 
repair mechanisms, immunological alterations, and the increase of viral replication (Robison, 1992; Xavier \& Taub, 2010). If it is true that trisomy 21 can increase the proliferation of normal lymphoid progenitors, then for the children with DS (who already have a genetic susceptibility) to develop leukemia, this proliferation must be accompanied by additional events such as exposure of these children to environmental risks (Levanon et al., 2001; Rabson, 2010; Ross, 1999). Several environmental factors have been studied in children with DS: exposure in utero to X-rays; post-natal exposure to ionizing radiation, certain chemicals (such as pesticides and benzene), or to electromagnetic fields (EMF); habits of the parents, such as alcohol consumption and tobacco use before and during the pregnancy, or vitamin consumption; and viral infections of the mother during the pregnancy or of the child after birth.

\section{Environmental factors associated with development of $A L$ in children with DS}

There have been relatively few studies concerning the association between exposure to environmental factors and the development of AL in children with DS; a brief description of the findings of these studies is germane to the current discussion.

Linabery et al. (2006) and the COG carried out a case-control study to determine if there were an association between exposure to radiation (X-rays) and the development of AL in children with DS. Of the 158 children with DS and AL who were identified from the registration files of COG, 97 had ALL and 61 had AML); the controls, 173 healthy children with DS, were selected from the same primary-care hospitals or clinics where the cases were treated in a normal fashion before their being diagnosed with AL. Three periods of possible exposure to radiation were studied; these were prior to conception, in utero, and postnatal. Data for the variable of the study was obtained by means of a telephone interview with the parents. In this interview, the parents were asked about any episodes of exposure to radiation (X-rays) during these periods. The results showed that there was no association between exposure to radiation and the development of ALL and AML in children with DS. The limitations of this study are due to the manner in which the exposure was measured and to the fact that the type of radiation, the radiation dose, and the part of the body exposed were not taken into account. In addition, it is probable that there had been a bias in the identification of the controls: not all the primary-care physicians furnished a list of potential controls; therefore, the authors had to seek a care center different than the one that had treated the case.

Data from these same groups of children were used in another case-control study conducted by the COG to determine if exposure of the mother to pesticides in the home was associated with the risk of AML or ALL in their children with DS. Positive associations with the development of ALL were found for exposure to pesticides in the home (odds ratio (OR): 2.25; 95\% confidence interval (CI): 1.13, 4.49); to a pesticide (OR: 2.18; 95\% CI: 1.08, 4.39); and to a chemical (OR: 2.72; 95\% CI: 1.17, 6.35). No statistically significant association for AML was found in children with DS. The notable limitation in this study is that a third of the mothers and physicians were unable to provide data for the potential controls, so that another physician was consulted (Alderton et al., 2006).

Another case-control study concerned the relation between parental habits (smoking tobacco and alcoholism by the father) prior to the pregnancy or the passive exposure of the child to tobacco smoke and the development of leukemia by the child with DS. In this study, 
the sample size was 27 children with DS who had leukemia $(\mathrm{ALL}=22 ; \mathrm{AML}=5)$ and 58 controls who were recruited from institutions of special education for children with DS. The parents of the case children and control children were interviewed concerning the frequency of their exposure to tobacco in the year prior to the pregnancy and during the pregnancy and concerning the passive exposure of the child to tobacco smoke prior to diagnosis (MejíaAranguré et al., 2003). Risk of the child with DS to develop AL was associated with the father's having smoked during the year prior to the pregnancy (OR: 3.57; 95\% CI: 0.82, 20.27); with the father's having consumed alcohol in the year prior to the pregnancy (OR: $3.10 ; 95 \%$ CI 1.12, 8.62; and with the child with DS having been passively exposed to tobacco smoke (OR: 3.39; 95\% CI: 1.09, 10.48). Although the sample size was small, important associations were encountered. However, it is probable that there was a bias in the selection of the control group.

Another of the factors that have generated numerous studies is the relation of the exposure of children to magnetic fields (MF) and the development of AL. This study was carried out with children with DS: 42 children had DS and ALL, with 124 healthy children with DS as controls. The controls were recruited from institutions providing special education to children with DS. The principal variable of exposure was measured in the home of the child by means of a gausometer, in addition to visual inspection of the wiring around the house. For each of the children, the parents were interviewed by health-care personnel at the attending health-care center. The data so obtained indicated that there was a positive association when there had been an exposure to MF >6.00 mG (OR: 3.7; 95\% CI: 1.05, 13.1). It is interesting to note that, despite the few number of cases, the risk was found to be high, thus showing that, for children with a high susceptibility to environmental exposures that carry a risk, such factors become evident even though few individuals are studied. Nonetheless, it is probable that this study contains the same selection bias as the previous study (Mejía-Aranguré et al., 2007).

Puumala et al. (2007) conducted a case-control study to determine whether the reproductive history of the mother or infertility treatment was associated with a risk for the children with DS to develop ALL or AML. As mentioned earlier in this section, of the 158 cases captured by COG, 97 were diagnosed with ALL and 61, with AML; the 173 controls were healthy children with DS. To measure the variable of exposure, a telephone interview was carried out, evaluating the reproductive history and infertility treatment. The results were null; only an association between AML in children with DS was reported when an infertility treatment had been performed one year prior to the pregnancy (OR: 2.22; 95\% CI: 1.14, 4.33). The possible limitations to this study are that the controls were recruited from the same clinic from which the cases had been recruited; however, a list of potential controls was not always available. Also, there could have been a memory bias when measuring the principal variable.

Ross et al. (2005b) studied the consumption of vitamins close to the time of conception and its association with the development of AL in children with DS. This case-control study utilized the same 158 children with DS and AL (97 cases with ALL; 61 with AML) that had been identified by COG and 173 healthy children with DS as controls. The mother of each child was interviewed by telephone to obtain information concerning the consumption of these supplements prior to the pregnancy and both before and after realizing that she was pregnant. A decrease in the risk of leukemia was observed when the vitamins had been taken as supplements during the periconception period (OR: $0.63 ; 95 \% \mathrm{CI}: 0.39,1.00)$. When stratified by type of leukemia, the risk of ALL was reduced (OR: 0.51; $95 \%$ CI: 0.30, 0.89); this 
was not found for AML (OR: 0.92; 95\% CI: 0.48, 1.76). Consumption of vitamins during the periconception period after the realization of the pregnancy was associated with an increase in the risk of leukemia (OR: 1.61; 95\% CI: 1.00, 2.58), for both ALL and AML. It should be pointed out that there was a possible confusion bias due to the increased risk of consuming vitamins by the mother after becoming pregnant; therefore, an underlying biological process could confound the study.

The role of infections in the etiology of leukemia and DS also has been under intensive study. By means of a case-control study using the same group of patients taken from the COG registry (the number of patients, recruitment of the controls, and measurement of the variable were given in more detail in foregoing paragraphs), the Children's Oncology Group (COG) evaluated the association between both the mother's state of health and episodes of infections during the pregnancy and the development of AL. The results obtained showed that the health problem most frequently encountered during pregnancy was vaginal bleeding, which had an associated reduction in the risk for AL for all the cases (OR: 0.57; 95\% C: 0.33,0.99). The mother's having undergone amniocentesis was associated with an increase in the risk for AML (OR: 2.06; 95\% CI: 0.90,4.69). One of the biases in this study is that of memory, due to the length of time between the pregnancy and the study interview (Ognjanovic et al., 2009).

In a case-control study that used this same group of children (details of the COG study, including cases, controls, and interview are given in foregoing paragraphs), Canfield et al. (2004) studied whether early infections in children with DS, as well as infections that the mothers underwent during pregnancy, played a role development of AL. In this study, it was found that there was a negative association between the risk of $\mathrm{AL}$ and any infection during the first two years of life: OR: 0.55: 95\% CI: 0.33,0.92 for combined AL; OR: 0.53; 95\% CI: $0.29,0.97$ for ALL; and OR: 0.59; 95\% CI: 0.28,1.25 for AML.

Similarly, Flores-Lujano et al. (2009) investigated whether either infections or breastfeeding was associated with risk of AL in children with DS. In this case-control study, the sample size was 57 children with DS and AL (45 ALL and 12 AML), with 218 healthy children with DS as controls. The controls were recruited from centers of special education for children with DS. Health-care personnel carried out the interviews in the health-care centers and in the special education institutions. In these interviews, questions specifically focused on infections and hospitalization in the first year of life and on breastfeeding. Although a statistically significant association was not found for these factors and general $\mathrm{AL}$, hospitalization for an infection during the first year of life increased the risk (OR: 3.57; 95\% CI: $1.59,8.05)$. Together with the foregoing results, this indicates that alteration of the immunological micro-environment could increase the risk for the development of AL in children with DS. A characteristic of these children is their having a higher frequency of infections than children without DS. This aspect should be investigated in greater depth.

\section{Infection and leukemia in children}

\subsection{Infections and space-time clustering of children with childhood leukemia}

The theme of viral infections and childhood leukemia has been approached through cluster analysis. The findings are interpreted in both a time and space context. Due to studies of this type, possible evidence has been postulated that support the idea of an infectious etiology in childhood leukemia (Francis et al, 2011; McNally et al, 2009). Studies of this type describe geographical and historical units, not individuals or populations per se. Though the results of such studies make reference to individuals and populations, the interpretations given have to be placed on a time line or in a geographical territory. 
Under the foregoing terms, a cluster consists of a group of persons, who group together, whether temporally, geographically, or both temporally and geographically. When found to cluster simultaneously both temporally and geographically, this phenomenon is known as space-time clustering.

McNally and Eden (2004) commented that if infections are implicated in the etiology of childhood leukemia, then the geographic distribution of those children would demonstrate a space clustering within a determined time frame (McNally \& Eden, 2004); that is to say, that they would form a space-time clustering.

With the premise that a space-time clustering can show evidence of an infectious etiology for children with leukemia, we performed a revision of the publications that concern this theme by availing ourselves of the information retrieval system provided by Pub Med, PubMed is a free database maintained by the United States National Library of Medicine at the National Institutes of Health. We compared the number of cluster-analysis studies in general with that of studies that specifically dealt with space-time clustering. Then, we further refined the search to retrieve the space-time studies that concerned children with leukemia. Finally, we made a brief description of the type and number of the publications that had been done concerning space-time clustering and children with leukemia (Table 1; Fig. 1).

\begin{tabular}{|l|c|}
\hline \multicolumn{1}{|c|}{ Key word } & \multicolumn{1}{c|}{$\begin{array}{c}\text { Number of } \\
\text { publications }\end{array}$} \\
\hline Cluster analysis & 59761 \\
\hline Cluster analysis + Leukemia & 1292 \\
\hline $\begin{array}{l}\text { Cluster analysis + Childhood + } \\
\text { Leukemia }\end{array}$ & 168 \\
\hline Space-time clustering & 1801 \\
\hline Space-time clustering + Leukemia & 124 \\
\hline $\begin{array}{l}\text { Space-time clustering + Childhood + } \\
\text { Leukemia }\end{array}$ & 61 \\
\hline
\end{tabular}

Table 1. Number of publications retrieved by iterative searches of PubMed database by using distinct key words. (Access date: 4 March 2011)

The key words (cluster analysis, space-time clustering; leukemia; childhood) utilized in PubMed were chosen because they are medical subject headings (MeSH), a controlled vocabulary for indexing articles in PubMed. These predetermined terms are used in the PubMed database to avoid omission of some study related to the theme of the search. We did not select any other limitation to annotate the search. The quantity of publications $(59,761)$ retrieved when the term "cluster analysis" was used as the sole search word shows that this type of study is used widely. However, it should be noted that this number includes not only studies of clustering, but also studies by clustering.

When "space-time clustering" was used as the search term, the results were distinct: 1801 publications were retrieved. Of the 124 space-time clusterings concerning leukemia, approximately one half (61) dealt with childhood leukemia. These publications started in 1968 with a study, presented at a symposium, which was published in Nippon Ketsueki Gakkai Zasshi (Hirayama, 1968). In 1969, Glass \& Mantel (1969) published a study 
concerning children in Los Angeles, California, in which mortality data were used in an exceptional way.

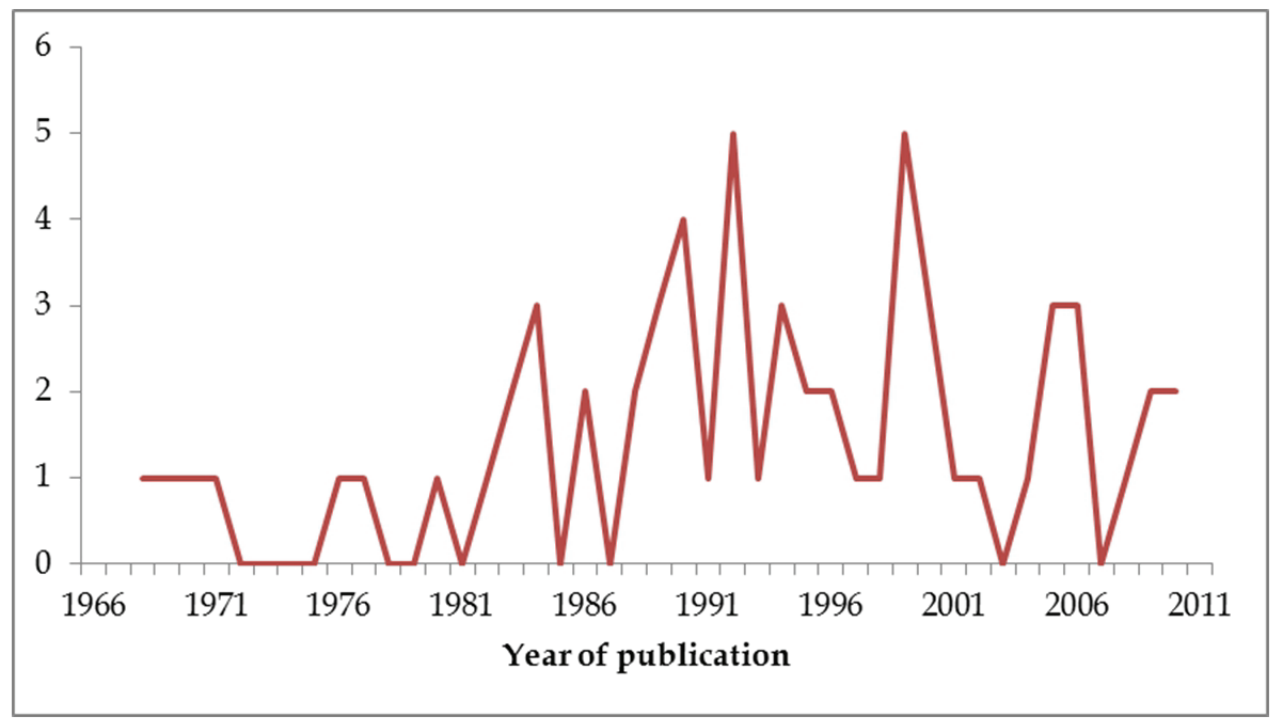

Fig. 1. Quantity of publications, retrieved by iterative searches of PubMed (see text), concerning both space-time clustering and childhood leukemia

The annual publication rate of such studies increased slowly until reaching a maximum in 1991; thereafter they started to decline. However, since the end of the last century, there appeared new peaks, notably in 1999, 2005, and 2009, thus showing a possibly renewed interest in performing this type of study.

The reason that such studies are performed may be due to the fact that populations worldwide live within a demarked time and geographical area. Infections are processes that are also limited to a time, to a space, and to a population. These studies cannot demonstrate solid support for any relation, but their consistency can provide a very strong argument. The two principal hypotheses of the concept of the infectious etiology of childhood leukemia, those postulated by Greaves (1988) and by Kinlen (1988), have been consistently supported by these cluster analysis studies and their results inspire other researchers to continue studies on this possible relation.

\subsection{Viral theories of cancer and leukemia}

In the first half of the last century, the viral theory of cancer and leukemia was almost in disrepute. So much so, that there was great difficulty in obtaining funds or laboratory facilities for research projects dealing with the hypothetical virus origin of cancer (Gross, 1974). In 1951, it was demonstrated that a transmissible virus causes mouse leukemia (Gross, 1951a). In those experiments, when inoculated into newborn mice of a non-leukemic inbred strain, filtrates prepared from leukemic mouse tissues were found to induce leukemia or lymphosarcomas. Complicated genetic theories had been used to explain the phenomenon of the development of "spontaneous" leukemia in successive generations of mice of certain inbred lines, such as AK 
or C58. However, the correct explanation was provided by the demonstration that mouse leukemia virus is transmitted, in a latent form, from one generation to another directly through the embryos (Gross, 1951b), probably through the germinal cells (Ahmed, 2005). The activation of the virus may not occur during the lifespan of the carrier host and the host may remain in good health, even though it carries the virus and transmits it to its progeny. A variety of tumors and leukemias in several animal species were found to be caused by filterable viruses, transmissible by inoculation of newborn host. The mouse-leukemia virus induces leukemia not only in mice but also in rats; it can be transmitted from rat-to-rat filtrates (Gross, 1963). Cat leukemia was found to be caused by a virus transmissible by filtrates not only from cats but also from dogs (Jarrett et al., 1964; Rickard et al., 1973, as cited in Dutcher \& Chieco-Bianchi, 1973). It is still not understood why certain tumors and leukemias, such as mammary tumors in mice or leukemia in mice, cats, or chickens, contain virus particles and can be readily transmitted to other hosts by filtered extracts; similar tumors and lymphomas, which develop naturally in other species such as dogs, rats, and humans, do not seem to contain virus particles. This may be due to improper experimental methods; for example, no virus particles had been found in bovine lymphosarcoma until these leukemic cells were placed into shortterm tissue cultures (Gillet et al., 2007).

In 1969, in an apparent attempt to elucidate the role of viruses in the etiology of cancer, Todaro and Huebner (1972) proposed the "oncogene" theory, suggesting that most cells of vertebrates carry, as an essential part of their natural evolutionary inheritance, "oncogenic information" (the oncogene), and that cancer results from the destruction of the normal "repressor system" that keeps both the oncogenic and virogenic information in check in the normal adult cell. In other words, "endogenous virogenes" (genes for the production of type-C viruses) and oncogenes (the portion of the virogene responsible for transforming a normal cell into a tumor cell) were maintained in an unexpressed form by "repressors" in normal cells. Agents, such as radiation, chemical carcinogens, or the normal process of aging, could activate the genes and may transform cells by "switching on" the endogenous oncogenic information (Huebner \& Todaro 1969; Todaro \& Huebner, 1972). Gross (Gross, 1963; Jarrett, 1964; Rickard et al., 1973, as cited in Dutcher \& Chieco-Bianchi, 1973) pointed out that there is a fundamental difference between the vertical theory and the oncogene theory (Gross, 1963). The concept of vertical transmission of oncogenic viruses assumes that, at some point, the oncogenic viruses entered the animal host from outside and, since that time, have been passed from one generation to the other as a latent infection (Jarrett, 1964), whereas the "oncogene" theory postulates that the genome responsible for producing the infectious virus is part of the inherited genetic material of all cells of normal vertebrates. Gross furthered commented that, in the former case, the oncogene theory would be very similar to the original concept of vertical transmission of latent oncogenic viruses, with only some significant changes in terminology and with the assumption that latent oncogenic viruses are present in almost all somatic cells of vertebrates. If the oncogene theory assumes that infectious viruses can be produced from normal endogenous components of healthy, normal not infected cells, then such a concept would be untenable, without returning to the old concept of spontaneous generation of infectious agents (Rickard et al., 1973, as cited in Dutcher \& Chieco-Bianchi, 1973).

\subsubsection{Kinlen's hypothesis}

Infection has been causally linked to some leukemias in animals and in adult humans and has often been considered as a basis for childhood leukemia. If childhood leukemia does 
have such an origin, the lack of an appreciable space-time clustering suggest that the infection is spread mainly by trivially infected subjects, rather than by children with leukemia. In 1990, Kinlen suggests that childhood leukemia represents a rare response to a much commoner, perhaps an unidentified mild or subclinical, infection, the transmission of which is facilitated when large number of people come together, particularly when they are from a variety of origins (Kinlen et al., 1990). This hypothesis was discussed in a study that showed a significant increase in childhood leukemia in a rural district in Scotland. This area, located at a distance from a conurbation and having no nuclear power installation in the vicinity, experienced a large influx of people during the 1950's (Kinlen, 1988) . Kinlen mentions that, when evaluating the findings, it is crucial to take into consideration the factors that are likely to increase the scale of contacts between susceptible people and the carriers of an unrecognized infection. Such factors, in the presence of that infection, may promote the development of leukemia and probably an epidemic of the infection itself, producing discernible long-term effects. Contact between those infected and susceptible individuals is the basis for the spread of any infection. That the total number of potential contacts is of great importance has been shown in occupational studies of infections such as influenza (Oxford et al., 2005) and tuberculosis (Hewitt \&Stewart, 1951), as well as in the description of outbreaks of many other infections. New contacts between members of different communities must have occurred on an unusual scale both directly and indirectly as new towns rapidly grew in this area (Kinlen, 1988). Kinlen added that the greater the diversity in geographic origins among sizeable groups of residents, the more likely it is that appreciable differences in herd immunity will be found among different subgroups. The rate of progress of an epidemic is primarily regulated by the number of susceptible people and by the rate of contact between those infected and susceptible people (Fox et al.,1971). The best-known cluster of childhood leukemia is that in Niles, Illinois, USA, which consisted of eight cases during 1957-60, seven of whom were pupils of a single parish school. The population of Niles grew from 3587 in 1950 to 20393 in 1960, with most of the increase occurring in 1955-60 and in the parish that later experienced the leukemia cluster (Heath \& Hasterlik, 1990). The increased opportunity for new contacts, both in the crowed parish school (class size of 50) and in the adjoining church, could have favored both transmission of an infectious agent and repeated exposure to infected individuals.

\subsubsection{Greaves' hypothesis}

Greaves (1986) proposed that, at its peak incidence at about ages 3 and 4 years, ALL is due not to specific viruses, but to mutations that may delay exposure to various non-specific infective agents as well as to other immunological challenges (Greaves, 1986). Kinlen (1990) implied that, as this hypothesis is difficult to test epidemiologically, it would be problematic to distinguish definitively such effects from those of specific agents, as are observed in the majority of infection-based illnesses (Kinlen, 1990).

Kinlen (1990) concluded that their findings provide support not only for infection being a basis for childhood leukemia (not only the lymphatic type), but also specifically for an infection being promoted by greater levels of social contact, particularly among people from communities that previously has been widely separated. In locales where an excess of childhood leukemia has been recorded, the dynamics of herd immunity in such communities, taken as a whole, must be given greater attention.

Furthermore, Greaves and Chan suggest that much of the variation reported in the literature is a consequence of selective under-reporting and premature death in places where socio- 
economic conditions are poor (Den Otter et al., 1986). They also pointed out that the rate of lymphocyte proliferation in early childhood will be influenced by the pattern of exposure to micro-organisms, which will vary with social, environmental, and geographical factors. The idea of spontaneous mutations is not new. In one study, Den Otter et al. (1987) attempted to calculate both the incidence of the so-called "endogenous malignancy" and the number of mutations required for carcinogenesis by using measured mutant frequencies (Gross, 1951). Morris (1989) referred to the Den Otter study when he proposed an improved mathematical formula for application specifically to the incidence of lymphoid malignant (Morris, 1989). Morris concluded that his mathematical model showed that, if an increased mutation rate affects a subset of cell divisions, then the number of cell generations affected is more important than the absolute number of cell divisions affected. He is aware that the model he proposed fails to explain the age distribution of ALL without an additional assumption of a fallible mechanism that normally would eliminate malignant-clones. In this case, the activation of one growth-control gene by the loss of two regulatory genes would be enough for neoplasia.

\subsubsection{Alexander's hypothesis}

The Leukaemia Research Fund Data Collection Survey (DCS) is a specialist registry of leukemias and lymphomas, which collects high-quality incidence data for about half of England and Wales. The DCS published an atlas for 1984-88 (Alexander et al., 1991), in which the incidence of childhood ALL recorded by the registry was related both to aspects of community lifestyle from the 1981 census of England and Wales and to the Ordnance Survey digitized 1/625000 map data. The main findings were tested by applying them to the Yorkshire Region Children's Tumor Registry (YRCTR) for 1974-83. Although Yorkshire is in the DCS area, the two data sets are independent because the time periods do not overlap. Alexander considered these data and found that the association between ALL and radon persisted after adjustment for lifestyle factors (Cartwright et al, 1990). It was observed that higher rates of leukemias in children and young people had been reported in areas of higher socio-economic class and socio-economic status. These considerations led to the hypothesis that the incidence of childhood ALL was higher in communities that were isolated, were of higher socio-economic status, and had substantial numbers of commuting individuals. The relevant factors and classifications by each individually were selected in advance of the inspection of incidence data. The findings did not support any association between childhood ALL and commuting-to work distances. However, there was significant evidence that incidence increases, particularly for the childhood peak-age range, with distance from built-up areas. Further analysis of the DCS data showed that the highest rates of childhood ALL were found in those "middle-class" towns and villages which were farthest from urban conurbations. Initial confirmation was given by YRCTR data, with a similar two-fold difference in risk in both data sets. Alexander suggested that the interpretation of the findings and those of Kinlen (Kinlen,1988,1990) and of Cook-Mozaffari et al. (CookMozaffari et al.,1989) was that the lifestyle in isolated communities, i.e., those of higher economic status, is conducive to an unusual exposure to some specific infectious agent or to general infections. This exposure can, in turn, increase the risk of childhood leukemia.

In contrast, Greaves model proposes that no specific agent is involved, but that the reduced exposure to antigenic challenge in infancy leads to greater proliferation of pre-malignant clones that can experience a second malignant change as a result of later infection (Greaves \& Chan, 1986). Alexander mentioned that, if it is the timing of exposure to infections that is 
relevant, then the results found would strongly support the first part of Greaves hypothesis, when it can be shown that the children in the isolated communities experience reduced antigenic challenge in infancy. Therefore, the earliest social grouping may provide an environment particularly conducive to the spread of infections (Davis, 1986) which, Greaves suggests, would facilitate the second malignant event. The authors conclude that their findings tend to favor Greaves model, but further investigations of these communities will be straightforward and have the potential to refine the infection-as-causal-agent models for the etiology of childhood ALL. Possible interpretations include germ-cell damage prior to conception (Fairlie, 2009; Gardner et al., 1990), synergism between viruses and radiation (Pinkel \& Nefzger, 1959), and some unknown extra factor.

\subsection{Infection during the first year of life and childhood leukemia. Epidemiological evidence}

Epidemiological studies have been performed to determine whether an infection during the first year of life is a factor that influences the causality of childhood AL, and specifically ALL. Kinlen and Greaves (1988) proposed that infections may be involved in reducing the risk of developing AL. For that reason, epidemiological studies have evaluated the relation between early infections and childhood AL. The infections that have been evaluated include otitis media, common colds, respiratory tract infections, streptococcus-caused infections, influenza, asthma, gastrointestinal diseases, infections causing diarrhea or vomiting, and infections that may have been recurrent in an early stage or that may have required hospitalization, such as exanthema-like diseases typical of infancy. These studies have demonstrated that exposure to such infections permit the stimulation and maturation of the immunological system of the child, thus reducing the risk that, when challenged by a later infection, the child's immune system would respond in an aberrant manner, resulting in AL. Given that the lymphoid leukemic cells represent a clonal expansion of white cells, these act in the human body as the first line of defense against infectious agents, that normally are regulated by lymphocytes, monocytes, and neutrophils, which in turn neutralize and eliminate the pathogenic agent. Therefore, if there is a aberrant or abnormal response to an infection, it could occasion in the child an excessive proliferation of mutated cells as the immunological response to the late infection, or else it could fails to halt the proliferation of malignant cells (Chan et al., 2002; Dockerty et al., 1999; Greaves \& Alexander, 1994; Greaves, 1988; Greaves, 2006; Jourdan-Da et al., 2004; Kinlen, 1988; McNally \& Eden, 2004; Ma et al., 2005a; Ma et al., 2009; Neglia et al., 2000; Perillat et al., 2002a; Rudant et al., 2010; Urayama et al., 2011; van Steensel et al., 1986).

The majority of studies carried out to evaluate this association have been epidemiological designs of the case-control type. Such studies have shown that, when children had been exposed to common infections during the first year of life, there was a reduction in the risk of developing AL. However, not all the studies have shown this association; thus, early infection as a causal agent of childhood AL remains a controversial issue. Nevertheless, the importance of early infection during the first year of life, whether resulting in a reduction or an increase in the risk of developing $\mathrm{AL}$, has not been discarded (Table 2)(Cardwell et al., 2008; Chan et al., 2002; Dockerty et al., 1999; Jourdan-Da et al., 2004; McNally \& Eden, 2004; McArthur et al., 2008; Ma et al., 2005a; Ma et al., 2009; Neglia et al., 2000; Perillat et al., 2002b; Petridou et al., 2001; Roman et al., 2007; Rosenbaum et al., 2000; Rudant et al., 2010; Shüz et al., 1999; Urayama et al., 2011; van Steensel et al., 1986;).

Some researchers have opted not only to evaluate the relation between early infections and $\mathrm{AL}$ by determining the involvement not only of common infections, but also of the 


\begin{tabular}{|c|c|c|c|c|}
\hline $\begin{array}{l}\text { Author, } \\
\text { Year } \\
\text { (Country) }\end{array}$ & $\begin{array}{l}\text { Van Steensel et al., } \\
1986 \\
\text { (The Netherlands) }\end{array}$ & $\begin{array}{l}\text { Schüz et al., } 1999 \\
\text { (Germany) }\end{array}$ & $\begin{array}{l}\text { Dockerty et al., } 1999 \\
\text { (New Zealand) }\end{array}$ & $\begin{array}{l}\text { Neglia et al., } 2000 \\
\text { (USA) }\end{array}$ \\
\hline $\begin{array}{l}\text { Design of } \\
\text { study }\end{array}$ & $\begin{array}{l}\text { Case-control study } \\
(1973-1980)\end{array}$ & $\begin{array}{l}\text { Case-control } \\
\text { study in two parts } \\
(1980-1994)\end{array}$ & $\begin{array}{l}\text { Case-control study } \\
(1991-1995)\end{array}$ & $\begin{array}{l}\text { Case-control study } \\
\text { (1 January } 1989 \text { and } \\
15 \text { June } 1993 \text { ) }\end{array}$ \\
\hline $\begin{array}{l}\text { Size of } \\
\text { sample }\end{array}$ & $\begin{array}{l}492 \text { cases, } 480 \\
\text { controls; age: } 0-14 \\
\text { years }\end{array}$ & $\begin{array}{l}1184 \text { cases, } 2588 \\
\text { controls; age: } 0-14 \\
\text { years }\end{array}$ & $\begin{array}{l}121 \text { cases, } 303 \text { controls; } \\
\text { age: } 0-14 \text { years }\end{array}$ & $\begin{array}{l}1842 \text { cases, } 1986 \\
\text { control; age: }<15 \\
\text { years of age }\end{array}$ \\
\hline $\begin{array}{l}\text { Data } \\
\text { collection }\end{array}$ & $\begin{array}{l}\text { Mailed } \\
\text { questionnaire; } \\
\text { addressed to } \\
\text { diagnosis }\end{array}$ & $\begin{array}{l}\text { Telephone } \\
\text { interviews of } \\
\text { parents }\end{array}$ & $\begin{array}{l}\text { Mothers interviewed at } \\
\text { home; standardized } \\
\text { questionnaires and } \\
\text { serological tests }\end{array}$ & $\begin{array}{l}\text { Structured } \\
\text { interview }\end{array}$ \\
\hline Variables & $\begin{array}{l}\text { Breast feeding; birth } \\
\text { order; family size; } \\
\text { social class; number } \\
\text { of rooms in } \\
\text { household; } \\
\text { infections; } \\
\text { hospitalization or } \\
\text { consultation for } \\
\text { infections; primary } \\
\text { infections (measles, } \\
\text { chickenpox, mumps, } \\
\text { or rubella); periods } \\
\text { of fever }\end{array}$ & $\begin{array}{l}\text { First-born child; } \\
\text { duration of } \\
\text { breastfeeding; } \\
\text { deficit in social } \\
\text { contacts; routine } \\
\text { immunizations; } \\
\text { infections; } \\
\text { tonsillectomy or } \\
\text { appendectomy; } \\
\text { allergy of the } \\
\text { child; allergy of } \\
\text { the mother }\end{array}$ & $\begin{array}{l}\text { Social class, marital } \\
\text { status, ethnic group, } \\
\text { educational level of } \\
\text { parent; home } \\
\text { ownership; length of } \\
\text { gestation; age of mother } \\
\text { at child's birth; weight } \\
\text { of child at birth; } \\
\text { exposure of mother to } \\
\text { X-rays during the first } \\
\text { trimester; exposure of } \\
\text { child to X-rays or } \\
\text { radiotherapy before } \\
\text { onset of illness. Tobacco } \\
\text { smoking by mother in } \\
\text { first trimester or before } \\
\text { pregnancy }\end{array}$ & $\begin{array}{l}\text { Interview of } \\
\text { mother; gender; } \\
\text { age; race; } \\
\text { educational level of } \\
\text { mother; } \\
\text { educational level of } \\
\text { father; family } \\
\text { income; } \\
\text { immunophenotype } \\
\text { class. }\end{array}$ \\
\hline $\begin{array}{l}\text { Odds ratio } \\
\text { and } \\
\text { relevant } \\
\text { results }\end{array}$ & $\begin{array}{l}\text { Common colds RR: } \\
0.8,(95 \% \text { IC: } 0.6-1.0) ; \\
\text { periods of fever RR: } \\
0.9 ;(95 \% \text { IC: } 0.7-1.2) ; \\
\text { primary infections } \\
\text { RR: 0.8; (95\% IC: 0.4- } \\
\text { 2.0); these variables } \\
\text { were adjusted by } \\
\text { birth order, family } \\
\text { size, social class, and } \\
\text { residential space. } \\
\text { Infectious diseases } \\
\text { requiring } \\
\text { hospitalization RR: } \\
0.6 ;(95 \% \text { IC: } 0.4-1.0) .\end{array}$ & $\begin{array}{l}\text { Routine } \\
\text { immunizations } \\
\text { between } 0-3 \text { years } \\
\text { of age OR: } 3.2 ; \\
\text { (95\% IC: } 2.3-4.6 \text { ); } \\
\text { tonsillectomy or } \\
\text { appendectomy (at } \\
\text { least one) OR: } 1.4 \text {; } \\
\text { (95\% IC: } 1.1-1.9) ; \\
\text { child with allergy } \\
\text { OR: } 0.6 \text {; (95\% IC: } \\
0.5-0.8) \text { Having } \\
\text { had tonsillectomy } \\
\text { or appendectomy } \\
\text { increased child's } \\
\text { risk of developing } \\
\text { leukemia, whereas } \\
\text { allergies showed a } \\
\text { protective effect. }\end{array}$ & $\begin{array}{l}\text { A positive relation was } \\
\text { found between the } \\
\text { infection caused by } \\
\text { influenza during the } \\
\text { first year of life and the } \\
\text { risk for developing } \\
\text { leukemia OR: } 6.8 \text {; ( } 95 \% \\
\text { CI 1.8-25.7). No other } \\
\text { variable was related to } \\
\text { acute leukemia. }\end{array}$ & $\begin{array}{l}\text { Neither attendance } \\
\text { at, nor time } \\
\text { remaining in day } \\
\text { care was associated } \\
\text { with the risk of } \\
\text { developing } \\
\text { leukemia. For } \\
\text { children with 1-4 } \\
\text { episodes of ear } \\
\text { infections or } \\
\text { sustained } \\
\text { infections, the } \\
\text { association with } \\
\text { development of } \\
\text { acute leukemia was } \\
\text { not statistically } \\
\text { significant. }\end{array}$ \\
\hline
\end{tabular}

Table 2. Summary of reviewed articles concerning the epidemiology of early infection and acute childhood leukemia 


\begin{tabular}{|c|c|c|c|c|}
\hline $\begin{array}{l}\text { Author, } \\
\text { Year } \\
\text { (Country) }\end{array}$ & $\begin{array}{l}\text { Infante et al., } 2000 \\
\text { (Quebec, Canada) }\end{array}$ & $\begin{array}{l}\text { Rosenbaum } \\
\text { et al., } 2000 \\
\text { (New York, USA) }\end{array}$ & $\begin{array}{l}\text { Perillat et. al., 2002b } \\
\text { (France) }\end{array}$ & $\begin{array}{l}\text { Chan et al., } 2002 \\
\text { (Hong Kong) }\end{array}$ \\
\hline $\begin{array}{l}\text { Design of } \\
\text { study }\end{array}$ & $\begin{array}{l}\text { Case-control study } \\
\text { (1989-1995 }\end{array}$ & Case-control study & Case-control study & $\begin{array}{l}\text { A population based, } \\
\text { case-control study } \\
\text { (November } 1994 \text { and } \\
\text { December } 1997 \text { ) }\end{array}$ \\
\hline $\begin{array}{l}\text { Size of } \\
\text { sample }\end{array}$ & $\begin{array}{l}491 \text { cases } \\
491 \text { control } \\
\text { age: } 0-9 \text { years }\end{array}$ & $\begin{array}{l}255 \text { cases, } \\
760 \text { controls; } \\
\text { age: } 0-14 \text { years; } \\
31 \text { county region } \\
\text { (cases); } \\
(1980-1991)\end{array}$ & $\begin{array}{l}280 \text { incident cases; } \\
288 \text { hospital controls }\end{array}$ & $\begin{array}{l}116 \text { cases, } 788 \\
\text { controls; } \\
\text { Age: } 2-14 \text { years; the } \\
\text { Hong Kong } \\
\text { Paediatric } \\
\text { Haematology and } \\
\text { Oncology Study } \\
\text { Group }\end{array}$ \\
\hline $\begin{array}{l}\text { Data } \\
\text { collection }\end{array}$ & $\begin{array}{l}\text { Structured } \\
\text { questionnaire } \\
\text { administered to } \\
\text { mothers by telephone }\end{array}$ & $\begin{array}{l}\text { Standarized } \\
\text { questionnaires } \\
\text { mailed to the } \\
\text { parents }\end{array}$ & $\begin{array}{l}\text { Standarized face-to-face } \\
\text { interviews of the mothers }\end{array}$ & $\begin{array}{l}\text { Standarized, face-to } \\
\text { face interviews }\end{array}$ \\
\hline Variables & $\begin{array}{l}\text { Educational level of } \\
\text { mother; family } \\
\text { income at the time of } \\
\text { child's diagnosis; } \\
\text { mother's age; father's } \\
\text { age; tobacco smoking } \\
\text { by mother; infections } \\
\text { during pregnancy; } \\
\text { child's birth order; } \\
\text { attendance at day } \\
\text { care or nursery; } \\
\text { principal feeding } \\
\text { method (breast or } \\
\text { bottle); length of } \\
\text { breastfeeding; } \\
\text { history of recurrent } \\
\text { infections of mother; } \\
\text { use of antibiotics } \\
\text { during pregnancy }\end{array}$ & $\begin{array}{l}\text { Sex; race; } \\
\text { educational level } \\
\text { of mother; birth } \\
\text { order; feeding } \\
\text { status at birth } \\
\text { (breast, bottle); age } \\
\text { at diagnosis; day } \\
\text { care or preschool } \\
\text { program; family } \\
\text { outcome; maternal } \\
\text { employment } \\
\text { during the } \\
\text { pregnancy. }\end{array}$ & \begin{tabular}{|l|} 
Diagnosed categories \\
(acute leukaemia \\
classification and \\
immunophenotype); sex; \\
age; ethnic origin; \\
hospital where case \\
capture; educational \\
level of mother; \\
occupation of mother at \\
time interview, socio- \\
professional categories; \\
place of residence; birth \\
order; number of \\
siblings; day care; age at \\
start of day care; \\
repeated infections \\
before age 2 years; \\
surgical operation for \\
early ear-nose-throat \\
infections before age 2 \\
years; breastfeeding.
\end{tabular} & $\begin{array}{l}\text { Medical history } \\
\text { (infectious illnesses) } \\
\text { in the first year of } \\
\text { life; breastfeeding; } \\
\text { day care/social } \\
\text { contacts of index } \\
\text { and siblings; own } \\
\text { household } \\
\text { environment; } \\
\text { community } \\
\text { environment. }\end{array}$ \\
\hline $\begin{array}{l}\text { Odds ratio } \\
\text { and } \\
\text { relevant } \\
\text { results }\end{array}$ & $\begin{array}{l}\text { Early attendance at } \\
\text { daycare or at nursery } \\
\text { and breastfeeding } \\
\text { were protective } \\
\text { factors against the } \\
\text { development of acute } \\
\text { leukemia OR: } 0.49 \text {, }\end{array}$ & $\begin{array}{l}\text { Children who } \\
\text { attended day care } \\
\text { for }>36 \text { months, } \\
\text { compared with } \\
\text { those that did not, } \\
\text { had a lower risk } \\
\text { for developing }\end{array}$ & $\begin{array}{l}\text { An inverse association } \\
\text { was found between the } \\
\text { development of acute } \\
\text { leukemia and attendance } \\
\text { at day care OR: } 0.6 ;(95 \% \\
\text { CI: } 0.4-1.0) \text {, repeated ( } \geq 4 \\
\text { per year) early common }\end{array}$ & $\begin{array}{l}\text { Child had rubella } \\
\text { and/or fever during } \\
\text { first year of life } \\
\text { lowered the risk OR: } \\
0.33 \text {; (95\% CI: 0.16- } \\
0.68) \text {; change of } \\
\text { residence during }\end{array}$ \\
\hline
\end{tabular}




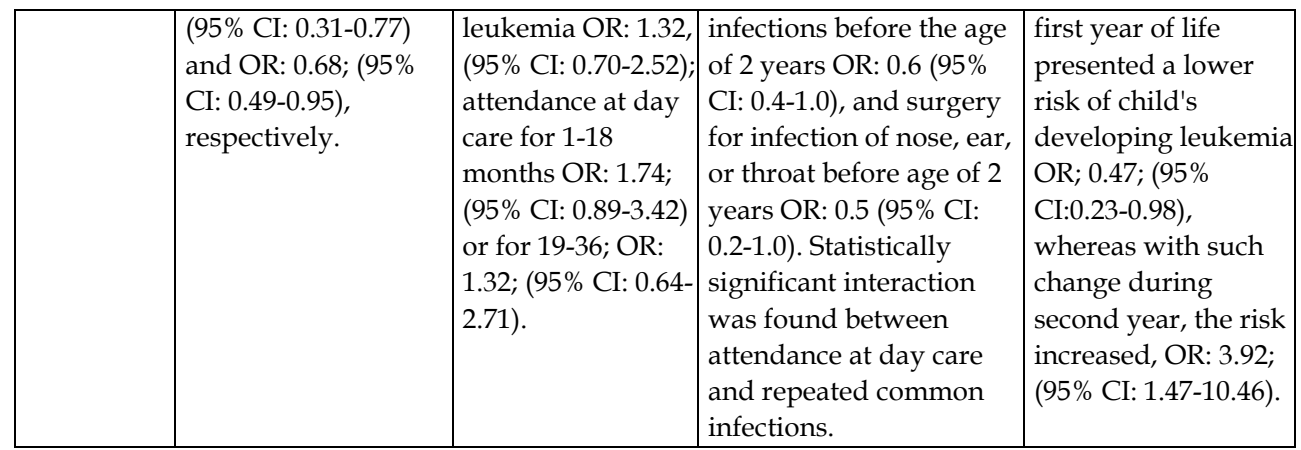

Table 2. (cont'd)

\begin{tabular}{|c|c|c|c|c|}
\hline $\begin{array}{l}\text { Author, } \\
\text { Year } \\
\text { (Country) }\end{array}$ & $\begin{array}{l}\text { Jourdan-Da } \\
\text { et al. 2004 } \\
\text { (France) } \\
\end{array}$ & $\begin{array}{l}\text { Rosenbaum P et } \\
\text { al., } 2005 \\
\text { (New York, USA) }\end{array}$ & $\begin{array}{l}\text { Ma et al., 2005b } \\
\text { (USA) }\end{array}$ & $\begin{array}{l}\text { Roman et al., } 2007 \\
\text { (United Kingdom) }\end{array}$ \\
\hline $\begin{array}{l}\text { Design of } \\
\text { study }\end{array}$ & $\begin{array}{l}\text { Case-control study } \\
(1995-1998)\end{array}$ & $\begin{array}{l}\text { Population-based } \\
\text { case-control study } \\
\text { (1980-1991) }\end{array}$ & & $\begin{array}{l}\text { Population-based, } \\
\text { case-control study } \\
\text { (1991-1996) }\end{array}$ \\
\hline $\begin{array}{l}\text { Size of } \\
\text { sample }\end{array}$ & $\begin{array}{l}473 \text { cases, } \\
567 \text { population-based } \\
\text { controls }\end{array}$ & $\begin{array}{l}255 \text { cases, } \\
760 \text { control; } \\
\text { age: } 0-14 \text { years }\end{array}$ & $\begin{array}{l}294 \text { incident cases, } \\
376 \text { controls; } \\
\text { age: } 0-14 \text { years }\end{array}$ & $\begin{array}{l}455 \text { cases, } \\
1031 \text { controls; } \\
\text { age: } 0-14 \text { years }\end{array}$ \\
\hline $\begin{array}{l}\text { Data } \\
\text { collection }\end{array}$ & Questionnaire & Questionnaire & $\begin{array}{l}\text { Personal interview of } \\
\text { parents }\end{array}$ & Interview of parents \\
\hline Variables & $\begin{array}{l}\text { Gender; age at } \\
\text { diagnosis; region of } \\
\text { residence at } \\
\text { diagnosis; socio- } \\
\text { professional } \\
\text { categories; } \\
\text { educational level of } \\
\text { mother; educational } \\
\text { level of father; birth } \\
\text { weight; term of } \\
\text { pregnancy; birth } \\
\text { order; mother's age } \\
\text { at birth; Down } \\
\text { syndrome; } \\
\text { breastfeeding; } \\
\text { infections in the first } \\
\text { year of life. }\end{array}$ & $\begin{array}{l}\text { Sex; race; birth } \\
\text { year; mother's } \\
\text { educational level; } \\
\text { family income; } \\
\text { maternal smoking; } \\
\text { infant feeding at } \\
\text { birth; birth order; } \\
\text { attended day care } \\
\text { before } 25 \text { months } \\
\text { of age; year of } \\
\text { diagnosis } \\
\text { leukemia; age at } \\
\text { diagnosis } \\
\text { leukemia; } \\
\text { allergies; history of } \\
\text { allergies; common } \\
\text { infections (colds, } \\
\text { otitis media, } \\
\text { influenza, croup, } \\
\text { bronchiolitis, } \\
\text { pneumonia, } \\
\text { vomiting, } \\
\text { diarrhoea) }\end{array}$ & $\begin{array}{l}\text { Age; gender; } \\
\text { household income; } \\
\text { mother's educational } \\
\text { level; mother's age at } \\
\text { birth; birth weight; } \\
\text { birth order; duration of } \\
\text { breast feeding; day- } \\
\text { care attendance; } \\
\text { infections during } \\
\text { infancy }\end{array}$ & $\begin{array}{l}\text { Sex; age; diagnoses } \\
\text { of infectious disease }\end{array}$ \\
\hline $\begin{array}{l}\text { Odds ratio } \\
\text { and } \\
\text { relevant } \\
\text { results }\end{array}$ & $\begin{array}{l}\text { Strong association } \\
\text { found if child had } \\
\text { gastrointestinal } \\
\text { illnesses; attendance }\end{array}$ & $\begin{array}{l}\text { Results showed } \\
\text { that infection late } \\
\text { in the first year of } \\
\text { child's life is }\end{array}$ & $\begin{array}{l}\text { Attendance at day care } \\
\text { and infections during } \\
\text { infancy is associated } \\
\text { with a decrease in the }\end{array}$ & $\begin{array}{l}\text { Cases had more } \\
\text { episodes of } \\
\text { infection than did } \\
\text { controls, which was }\end{array}$ \\
\hline
\end{tabular}




\begin{tabular}{|c|c|c|c|}
\hline $\begin{array}{l}\text { at day care lowered } \\
\text { risk OR: 0.6; (95\% CI: } \\
0.4-0.8) ; \text { no } \\
\text { association found for } \\
\text { breastfeeding; birth } \\
\text { order ( } 4^{\text {th }} \text { or later) } \\
\text { showed significant } \\
\text { association with } \\
\text { increased risk of } \\
\text { acute lymphoblastic } \\
\text { leukemia OR: } 2.0 ; \\
\text { (95\% CI: } 1.1-3.7) ; \\
\text { child's prior episode } \\
\text { of asthma was } \\
\text { associated with a } \\
\text { lower risk of } \\
\text { developing acute } \\
\text { lymphoblastic } \\
\text { leukemia OR: } 0.5 \text {; } \\
\text { (95\% CI: 0.3-0.9). }\end{array}$ & $\begin{array}{l}\text { associated with an } \\
\text { increment in the } \\
\text { risk of developing } \\
\text { leukemia. }\end{array}$ & $\begin{array}{l}\text { risk of developing } \\
\text { acute lymphoblastic } \\
\text { leukemia within the } \\
\text { white Hispanic } \\
\text { population OR: } 0.42 \text {; } \\
\text { (95\% IC: } 0.18-0.99 \text { and } \\
\text { OR: 0.32; (95\% IC: } 0.14- \\
\text { 0.74), respectively; } \\
\text { corresponding data for } \\
\text { the Hispanic } \\
\text { population, even for } \\
\text { those living in the same } \\
\text { area, did not agree. }\end{array}$ & $\begin{array}{l}\text { more notable in the } \\
\text { neonatal period ( } \leq 1 \\
\text { month): } 18 \% \text { of } \\
\text { controls and } 24 \% \text { of } \\
\text { cases with leukemia } \\
\text { were diagnosed } \\
\text { with an average of } \\
<1 \text { infection OR: } 1.4 \text {; } \\
(95 \% \text { CI: } 1.1-1.9 ; \\
\text { p }<0.05) \text {. Cases with } \\
\geq 1 \text { episodes of } \\
\text { infection in the } \\
\text { neonatal period } \\
\text { tended to be } \\
\text { diagnosed with } \\
\text { acute lymphoblastic } \\
\text { leukemia at a } \\
\text { relatively young } \\
\text { age. }\end{array}$ \\
\hline
\end{tabular}

Table 2. (cont'd)

\begin{tabular}{|c|c|c|c|c|}
\hline $\begin{array}{l}\text { Author, } \\
\text { Year } \\
\text { (Country) }\end{array}$ & $\begin{array}{l}\text { MacArthur, } \\
\text { et al., } 2008 \\
\text { (British Columbia } \\
\text { and Quebec, } \\
\text { Canada) }\end{array}$ & $\begin{array}{l}\text { Cardwell et al., } \\
2008 \\
\text { (United } \\
\text { Kingdom) }\end{array}$ & $\begin{array}{l}\text { Urayama et al., } 2010 \\
\text { (USA) }\end{array}$ & $\begin{array}{l}\text { Rudant J et al., } 2010 \\
\text { (France) }\end{array}$ \\
\hline $\begin{array}{l}\text { Design of } \\
\text { study }\end{array}$ & $\begin{array}{l}\text { Population-based, } \\
\text { case-control study } \\
\text { (January 1,1990 and } \\
\text { December } 31,1994\end{array}$ & $\begin{array}{l}\text { Nested } \\
\text { case-control } \\
\text { (cohort) study }\end{array}$ & $\begin{array}{l}\text { Case-control study } \\
(1995-1999)\end{array}$ & $\begin{array}{l}\text { National registry- } \\
\text { based, case-control } \\
\text { study ESCALE } \\
(2003-2004)\end{array}$ \\
\hline $\begin{array}{l}\text { Size of } \\
\text { sample }\end{array}$ & $\begin{array}{l}399 \text { cases, } \\
399 \text { controls; } \\
\text { age: } 0-14 \text { years }\end{array}$ & $\begin{array}{l}62 \text { cases, } \\
2215 \text { matched } \\
\text { controls }\end{array}$ & $\begin{array}{l}669 \text { cases, } \\
977 \text { controls; } \\
\text { age: } 1-14 \text { years }\end{array}$ & $\begin{array}{l}765 \text { incident cases, } \\
1,681 \text { controls. }\end{array}$ \\
\hline $\begin{array}{l}\text { Data } \\
\text { collection }\end{array}$ & $\begin{array}{l}\text { Standardized personal } \\
\text { interviews in the home } \\
\text { of child }\end{array}$ & Data-based & & $\begin{array}{l}\text { Questionnaire, } \\
\text { interviews by } \\
\text { telephone }\end{array}$ \\
\hline Variables & $\begin{array}{l}\text { Gender; age; mother's } \\
\text { age; father's age; } \\
\text { numbers of live births; } \\
\text { annual household } \\
\text { income; mother's } \\
\text { education; father's } \\
\text { education; ethnicity; } \\
\text { vaccinations; illness } \\
\text { and infections; } \\
\text { breastfeeding; } \\
\text { allergies; } \\
\text { immunosuppressant } \\
\text { medication for child; } \\
\text { vitamins; antibiotics } \\
\text { for child. }\end{array}$ & $\begin{array}{l}\text { Sex; age; } \\
\text { consultations; } \\
\text { numbers of } \\
\text { consultations; } \\
\text { antibiotics } \\
\text { prescriptions; } \\
\text { common } \\
\text { infections. }\end{array}$ & $\begin{array}{l}\text { Gender; mother's age } \\
\text { at child's birth; } \\
\text { mother's educational } \\
\text { level; annual } \\
\text { household income; } \\
\text { birth weight; breast- } \\
\text { fed; mother's } \\
\text { smoking; day-care } \\
\text { attendance; history of } \\
\text { common infections as } \\
\text { child; ethnicity. }\end{array}$ & $\begin{array}{l}\text { Mother's } \\
\text { educational level; } \\
\text { parental } \\
\text { professional } \\
\text { category; place of } \\
\text { residence at } \\
\text { diagnosis; mother's } \\
\text { age at child's birth; } \\
\text { number of children } \\
\text { of age < } 15 \text { years in } \\
\text { the household; birth } \\
\text { order; } \\
\text { breastfeeding; } \\
\text { duration of } \\
\text { breastfeeding; early }\end{array}$ \\
\hline
\end{tabular}




\begin{tabular}{|c|c|c|c|c|}
\hline & & & & $\begin{array}{l}\text { common infections; } \\
\text { surgical operation } \\
\text { for ear-nose-throat } \\
\text { infections; history } \\
\text { of allergies; contact } \\
\text { with animals; farm } \\
\text { visit before age of } 2 \\
\text { years }\end{array}$ \\
\hline $\begin{array}{l}\text { Odds ratio } \\
\text { and } \\
\text { relevant } \\
\text { results }\end{array}$ & $\begin{array}{l}\text { No association found } \\
\text { between early } \\
\text { infections and acute } \\
\text { leukemia; vitamin use } \\
\text { was associated with a } \\
\text { risk of developing } \\
\text { acute leukemia OR; } \\
\text { 1.66; ( } 95 \% \text { CI: } 1.18- \\
2.33 \text { ); with use of } \\
\text { immunosuppressors } \\
\text { by child, there was a } \\
\text { decrease in risk of } \\
\text { leukemia OR: } 0.37 ; \\
\text { (95\% CI: } 0.16-0.84) ; \\
\text { breastfeeding >6 } \\
\text { months had a } \\
\text { protective effect } \\
\text { against development } \\
\text { of leukemia (p <0.05). }\end{array}$ & $\begin{array}{l}\text { One or more } \\
\text { infections in the } \\
\text { first year of life } \\
\text { reduced the risk } \\
\text { of leukemia OR: } \\
10.5 ;(95 \% \mathrm{CI}: 0.69- \\
1.59 ; \\
\text { p = } 0.83) \text { and of } \\
\text { acute } \\
\text { lymphoblastic } \\
\text { leukemia OR: } \\
1.05 ;(95 \% \mathrm{CI}: 0.64- \\
1.74 ; \mathrm{p}=0.84) \text {. }\end{array}$ & $\begin{array}{l}\text { When variables were } \\
\text { evaluated separately, } \\
\text { both attendance at } \\
\text { day care at } 6 \text { months } \\
\text { of age and birth order } \\
\text { reduced the risk of } \\
\text { leukemia OR: } 0.90 \text {; } \\
\text { (95\% CI: } 0.82-1.00 \text { and } \\
\text { OR: } 0.68 ;(95 \% \text { CI: } \\
0.50-0.92) \text {, } \\
\text { respectively) in a } \\
\text { white non-Hispanic } \\
\text { population, but not in } \\
\text { a Hispanic } \\
\text { population; however, } \\
\text { if these children had } \\
\text { ear infections, then } \\
\text { the risk of developing } \\
\text { acute leukemia was } \\
\text { reduced OR: } 0.45 \text {, } \\
\text { (95\%CI: } 0.25-0.79 \text { ). }\end{array}$ & $\begin{array}{l}\text { Negative } \\
\text { associations were } \\
\text { found for children } \\
\text { with repeated } \\
\text { common infections } \\
\text { OR: } 0.7 \text {; (95\% CI: } \\
0.6-0.9) \text {; with a } \\
\text { history of asthma or } \\
\text { eczema OR: } 0.7 \text {; } \\
\text { (95\% CI: } 0.4-1.0) \\
\text { and OR: } 0.7 ;(95 \% \\
\text { CI: } 0.6-0.9) \text {, } \\
\text { respectively; with } \\
\text { attendance at day } \\
\text { care before } 1 \text { year of } \\
\text { age OR: } 0.8 \text {; (95\% } \\
\text { CI: } 0.6-1.1) \text {; and } \\
\text { with prolonged } \\
\text { breastfeeding OR: } \\
0.7 ;(95 \% \text { CI: 0.5- } \\
1.0) \text {. }\end{array}$ \\
\hline
\end{tabular}

Table 2. (cont'd)

\begin{tabular}{|l|l|}
\hline $\begin{array}{l}\text { Author, } \\
\text { Year } \\
\text { (Country) }\end{array}$ & $\begin{array}{l}\text { Urayama } \\
\text { et al., 2011 } \\
\text { (USA) }\end{array}$ \\
\hline $\begin{array}{l}\text { Design of } \\
\text { study }\end{array}$ & $\begin{array}{l}\text { Observational studies } \\
\text { (1993-2008) }\end{array}$ \\
\hline $\begin{array}{l}\text { Size of } \\
\text { sample }\end{array}$ & 14 case-control study \\
\hline $\begin{array}{l}\text { Data } \\
\text { collection }\end{array}$ & $\begin{array}{l}\text { Searches of Pub Med } \\
\text { database and } \\
\text { bibliographies of } \\
\text { publications. }\end{array}$ \\
\hline Variables & NA \\
\hline $\begin{array}{l}\text { Odds } \\
\text { ratio and } \\
\text { relevant } \\
\text { results }\end{array}$ & $\begin{array}{l}\text { Attendance at day care } \\
\text { is associated with a } \\
\text { reduced risk of acute } \\
\text { lymphoblastic } \\
\text { leukemia OR: 0.76; } \\
\text { (95\%CI: 0.67-0.87). }\end{array}$ \\
\hline
\end{tabular}

Table 2. (cont'd) 
environment in which the child may have been exposed to diverse infectious agents. Such is the case of attendance in a day care, taking this as a proxy variable to evaluate said infections. Given that in such environment, the child may be in very close contact to those with childhood diseases or other common diseases. This close contact would permit the child to become ill with greater or lesser ease; at the same time, the child's immune system would be stimulated, sooner or later, by such infections (Chan et al., 2002; Dockerty 1999; Jourdan-Da et al., 2004; Ma et al., 2005b; Ma et al., 2009; Perillat et al., 2002b; Rosenbaum et al., 2000; Urayama et al., 2010, Urayama et al., 2011).

Urayama et al. performed two epidemiological studies in the USA, one was a case-control study (Urayama et al., 2010) and the other, a meta-analysis (Urayama et al., 2011). In the meta-analysis, the objective was to evaluate the association between the stay in day care during infancy and the risk of developing AL. Specifically, they evaluated whether early exposure to infection protected the child from AL, concluding that exposure of a child to common infections at an early age reduced the risk of developing AL (OR: 0.76; 95\% CI: 0.67-0.87) (Urayama et al., 2010; 2011).

Studies carried out by Dockerty et al. (1999), Infante et al. (2000), Jourdan-Da et al. (2004), Ma et al. (2005b), and Perillat et al. (2002b) also supported these results. They showed that, if a child attends day care at an early age, the risk of developing leukemia is reduced. On the other hand, reports have been published that show no association between these infections or attendance in day care and the development of $\mathrm{AL}$, or that show that rather than being a protective factor these variables are in fact risk factors for developing leukemia. Examples of such studies are those of Cardwell (2008), Dockerty (1999), and Neglia et al. (2000).

\subsection{Breastfeeding and acute leukemia. Epidemiological evidence}

Some epidemiological studies have evaluated breastfeeding as a possible protective factor. Given that it stimulates the immune response of the child, breast milk should be considered as the primary vaccine that the child receives during the first months of life, protecting the child from infections during this stage. Breast milk contains $\operatorname{IgA}$ antibodies against microorganisms and food antigens to which the mother has been exposed; in addition, the milk provides the child with immunoglobulins IgG and IgM, which stimulate phagocytosis and which prevent contact between microorganisms and epithelial cells of the host. The milk also contains B- and T-cell lymphocytes that are converted into lymphopoietic cells derived from the thymus and the spleen or equivalent tissue; these lymphocytes synthesize antibodies IgA, IgG, and IgM. By protecting the child from infections during the first year of life, breast milk can have an impact on the morbidity and mortality caused by diseases. Children fed exclusively with breast milk have fewer infections than do those who were never breastfed (Field, 2005; Macías et al., 2006; Parker, 2001; Reverón, 1995).

These epidemiological findings are supported by several case-control studies which showed that breastfeeding plays an important role in reducing the risk for developing AL during infancy, as breastfeeding can influence the immune response to an infection, modulating the system's response to a challenge (Altinkaynak et al., 2006; Bener et al., 2001; Beral et al., 2001; Davis, 1998; Field, 2005; Guise et al., 2005; Infante et al., 2000; Ip et al., 2007; Kwan et al., 2004; Perillat et al., 2002a; Shu et al., 1995, 1999; Stuebe, 2009).

Meta-analyses of case-control studies have been performed in order to evaluate the role of breastfeeding. Guise et al. (2005) performed a systematic review of articles, published in different electronic databases, with the aim of evaluating the evidence concerning the effect of breastfeeding on the risk of developing childhood AL. These authors reviewed 111 
citations, of which they identified 32 articles that had access to the complete article. They concluded that, in at least half the articles that they reviewed, the results support the idea that breastfeeding reduces the risk of developing AL. Kwan et al. (2004) carried out a metaanalysis in order to quantify the findings concerning duration of breastfeeding and the risk of developing ALL and/or AML. They identified 14 case-control studies in which breastfeeding that lasted $<6$ months or $>6$ months was evaluated. Breastfeeding for $>6$ months was found to reduce the risk of developing ALL (OR; 0.76; 95\% CI: 0.68-0.84) and AML (OR: 0.85; 95\% CI: 0.73-0.98); with breastfeeding for $<6$ months, this reduction was not lost. Ip et al. (2007) also performed a systematic review to evaluate this association between breastfeeding and AL. They evaluated case-control three studies, the results of which showed that breastfeeding for $>6$ months is associated with a reduction in the risk of developing ALL (OR: 0.80; 95\% CI: 0.71-0.91). (Guise et. al., 2005; Kwan et al., 2004).

\subsection{Breastfeeding and acute leukemia in children with DS}

Very few studies have evaluated the effect of early infections and breastfeeding in children with DS. One such study was carried out by Canfield et al. (2004) in which they evaluated the relation between early infections and the development of $\mathrm{AL}$, while also evaluating breastfeeding in children with DS. Children with AL diagnosed between January 1997 and October 2002 were recruited through the COG. As mentioned in section 2, the sample size was 158 children with both DS and leukemia and 173 healthy children with DS as controls. For the children with DS who had had infections during the first two years of life, the risk of developing AL was reduced (OR: 0.55; 95\% IC: 0.33-0.92), as compared to the children who had been infection-free during that period (Canfield et al., 2004).

In contrast, the results of a study carried out in Mexico City in children with DS did not support the findings of Canfield. In this study evaluating whether breastfeeding and infections during the first year of life demonstrated an association with the development of AL in children with DS, it was found that breastfeeding showed a protective effect, while early infection showed a factor risk of developing AL (OR: 0.84; 95\% CI: 0.43-1.61 and OR: 1.70; 95\% CI: 0.82-3.52, respectively); however, these effects were not statistically significant. This study also evaluated hospitalization for these infections. The results showed that if a child $>6$ years of age presented an infection and in addition was hospitalized for said infection, the risk for developing AL was increased (OR: 3.57; 95\% CI: 1.59-8.05); therefore, these results do not support the hypothesis, proposed by Greaves, that infections are a protective factor against the development of this disease (Flores et al., 2009).

\section{Conclusions}

The fact that our results agreed with reports in the literature that maternal breastfeeding during the first six months of life appeared to be a protective effect in the development of AL in children under six years of age should be underscored. The natural practice of breastfeeding does not put either the children or their mothers at risk and does not increase the expenses for the family or for society; therefore, independent of the strength of the mother-child bond that it fosters, breastfeeding should be encouraged as a measure that may lower the risk of children suffering AL during the first years of life (Guise et al, 2005). However, serious infections appeared to be an important risk factor in the development of AL in children over six years of age, especially for children from a low socio-economic background. 
The role of infectious agents involved in these groups should be investigated if these are involved in the genesis of $\mathrm{AL}$, above all, in those that occur in children older than six years. To date, the study of children with DS, a population with an elevated susceptibility for AL, has proved to be a very efficient design in the search for environmental factors associated with the development of AL. By using this design in several studies, we have identified associations important to the genesis of ALs, even when the sample size was not very large. The rationale to continue to use this design is that, if ALs result from the interaction of susceptibility to the disease and exposure to different environmental factors, then the search for the effect of these environmental factors in a non-susceptible population will always lead to erroneous results, because the population not susceptible to ALs will not develop the disease no matter how long they are exposed to such environmental factors. This design is an effective and efficient tool for use in studies elucidating the epidemiology of AL. However these results only apply to one population with like susceptibility for developing AL than children with DS.

\section{Acknowledgments}

This work was supported by a grant (FIS/IMSS/PROT/056) from the Fondo de Investigación en Salud, México, and of projects financed by grants (2007-171223/FIS/IMSS/PROT/592 \& CB-2007-1-83949/FIS/IMSS/PROT/616) from the Consejo Nacional de Ciencia y Tecnología, México, through its division for the dissemination of the results of scientific investigation. We thank Veronica Yakoleff for translation of the original Spanish manuscript, editorial revision, and for helpful comments.

\section{References}

Ahmed, N. (2005). The vertical transmission of human immunodeficiency virus type 1: molecular and biological properties of the virus. Critical Reviews in Clinical Laboratory Science, Vol.42, No.1, (2005), pp.1-34, ISSN 1549-781X.

Alderton, LE.; Spector, LG.; Blair, CK.; Roesler, M; Olshan, AF.; Robison, LL. \& Ross, JA. (2006). Child and maternal household chemical exposure and the risk of acute leukemia in children with Down's syndrome: a report from the Children's Oncology Group. American Journal of Epidemiology, Vol.164, No.3, (August 2006), pp. 212-221, ISSN 0002-9262.

Alexander, F.; Ricketts, T.; McKinney, P. \& Cartwright, R. (1991). Community lifestyle characteristics and lymphoid malignancies in young people in the UK. European Journal of Cancer, Vol.27, No.11, (November 1991), pp.1486-1490, ISSN 0959-8049.

Altinkaynak, S.; Selimoglu, M.; Turgut, A.; Kilicaslan, B. \& Ertekin, V. (2006). Breast-feeding duration and childhood acute leukemia and lymphomas in a sample of Turkish children. Journal of Pediatric Gastroenterology and Nutrition, Vol.42, No.5, (May 2006), pp.568-572, ISSN 1536-4801.

Bener, A.; Denic, S. \& Galadari, S. (2001). Longer Breast-feeding and protection against childhood leukaemia and lymphomas. European Journal of Cancer, Vol.37, No.2, (January 2001), pp.234-238, ISSN 0959-8049.

Beral, V.; Fear, N.; Alexander, F. \& Appleby, P. (2001). Breastfeeding and childhood cancer. UK Childhood Cancer Study Investigators. British Journal of Cancer. Vol.85, No.11, (November 2001), pp.1685-1694, ISSN 1532-1827. 
Canfield, KN.; Spector, LG.; Robison, LL.; Lazovich, D.; Roesler, M.; Olshan, AF.; Smith, FO.; Heerema, NA.; Barnard, DR.; Blair, CK. \& Ross JA. (2004). Childhood and maternal infections and risk of acute leukaemia in children with Down syndrome: a report from the Children's Oncology Group. British Journal of Cancer, Vol.91, No. 11, (November 2004), pp. 1866-1872, ISSN 1532-1827.

Canfield, MA.; Honein, MA.; Yuskiv, N.; Xing, J.; Mai, CT.; Collins, JS.; Devine, O.; Petrini, J.; Ramadhani, TA.; Hobbs, CA. \& Kirby, RS. (2006). National estimates and race/ethnic-specific variation of selected birth defects in the United States, 19992001. Birth Defects Research. Part A, Clinical and Molecular Teratology, Vol. 76, No. 11, (November 2006), pp.747-756, ISSN 1542-0760.

Cantor, AB. (2005). GATA transcription factors in hematologic disease. International Journal of Hematology, Vol.81, No.5, (June 2005), pp. 378-384, ISSN 0925-5710.

Cardwell, C.; McKinney, P.; Patterson, C. \& Murray, L. (2008). Infections in early life and childhood leukaemia risk: a UK case-control study of general practitioner records. British Journal of Cancer, Vol.99, No.9, (November 2008), pp.1529-33, ISSN 1532-1827.

Cartwright R, Alexander F, McKinney P, Ricketts T, Hayhoe F, Clayton D. (1990). Leukaemia and Lymphoma: an atlas of distribution within areas of England and Wales 1984-1988. (1 1 st Edition), Leukaemia Research Fund, ISBN 0-950223050, London.

Chan, L.; Lam, T.; Li, C.; Lau, Y.; Li, C.; Yuen, H.; Lee, C.; Ha, S.; Yuen, P.; Leung, N.; Patheal, S.; Greaves, M. \& Alexander, F. (2002). Is the timing of exposure to infection a major determinant of acute lymphoblastic leukaemia in Hong Kong?. Paediatric and Perinatal Epidemiology, Vol.16, No.2, (April 2002), pp.154-165, ISSN 1365-3016.

Cook-Mozaffari, P.; Darby, S.; Doll R. Forman, D.; Hermon, C.; Pike, MC. \& Vincent, T. (1989). Geographical variation in mortality from leukaemia and other cancers in England and Wales in relation to proximity to nuclear installations. 1969-1978. British Journal of Cancer, Vol.59, No.3, (March 1989), pp. 476-485, ISSN 1532-1827.

Davis, S. Case aggregation in young adult Hodgkins disease. (1986). Etiologic evidence from a population experience. Cancer, Vol.57, No.8,(April 1986), pp.1602-1612, ISSN 1097-0142.

Davis, K. (1998). Review of the evidence for an association between infant feeding and childhood cancer. International Journal of Cancer supplement, Vol.11, Issue supplement 11, (March 1998), pp. 29-33, ISSN 0898-6924.

Den Otter, W.; Kotten, J. \& Derkinderen, D. (1986). A new model of oncogenesis. Anticancer Research, Vol.6, No. 3 pt B, (May-June 1986), pp. 509-514, ISSN 1476-069X.

Den Otter, W.; Kotten, JW. \& Derkinderen, DJ. (1987). Carcinogenesis revisited. Cancer Investigation, Vol.5, No.1, (1986), pp.69-74, ISSN 1532-4192.

Dockerty, J.; Skegg, D.; Elwood, J.; Herbison, G.; Becroft, D. \& Lewis, M. (1999). Infections, vaccinations, and the risk of childhood leukaemia. British Journal of Cancer, Vol.80, No.9, (July 1999), pp.1483-1489, ISSN 1532-1827.

Elagib, KE.; Racke, FK.; Mogass, M.; Khetawat, R.; Delehanty, LL. \& Goldfarb, AN. (2003). RUNX1 and GATA-1 coexpression and cooperation in megakaryocytic differentiation. Blood, Vol.101, No.11, (June 2003), pp. 4333-4341, ISSN 1528-0020.

Fairlie, I. (2009). Commentary: childhood cancer near nuclear power stations. Environmental Health, Vol.8, No.23, (September 2009), pp.43, ISSN 0250-7005.

Field, CJ. (2005). The immunological components of human milk and their effect on immune development in infants. The Journal of Nutrition, Vol.13, No.1, (January 2005), pp.1-4, ISSN 1541-6100. 
Flores, J.; Perez, M.; Fuentes, E.; Gorodezky, C.; Bernaldez, R.; Del Campo, M.; Martinez, A; Medina, A.; Paredes, R.; De Diego, J.; Bolea, V.; Rodriguez, M.; Rivera, R.; Palomo, M.; Romero, L.; Perez, P.; Alvarado, M.; Salamanca, F.; Fajardo, A. \& Mejía, J. (2009). Breastfeeding and early infection in the aetiology of childhood leukaemia in Down syndrome. British Journal of Cancer, Vol.101, No.5, (September 2009), pp.860864, ISSN 1532-1827.

Fong, CT. \& Brodeur, GM. (1987). Down's syndrome and leukemia: epidemiology, genetics, cytogenetics and mechanisms of leukemogenesis. Cancer Genetics and Cytogenetics, Vol.28, No.1, (September 1987), pp. 55-76, ISSN 0165-4608.

Fox, JP.; Elveback, L.; Scott, W.; Gatewood, L. \& Ackerman, E. (1971). Herd immunity; basic concept and relevance to public health immunization practices. American Journal of Epidemiology, Vol.94, No.3, (September 1971), pp.179-189, ISSN 1476-6256.

Francis, S.; Selvin, S.; Yang, W.; Buffler, P. \& Wiemels, J. (2011). Unusual Space-Time Patterning of the Fallon, Nevada Leukemia Cluster: Evidence of an Infectious Etiology. Chemico-biological interactions, DOI:10.1016/j.cbi.2011.02.019, (February 2011), ISSN 0009-2797.

Freeman, SB.; Bean, LH.; Allen, EG.; Tinker, SW.; Locke, AE.; Druschel, C.; Hobbs, CA.; Romitti, PA.; Royle, MH.; Torfs, CP.; Dooley, KJ. \& Sherman, SL. (2008). Ethnicity, sex, and the incidence of congenital heart defects: a report from the National Down Syndrome Project. Genetics in Medicine, Vol.10, No.3, (March 2008), pp. 173-180, ISSN 1530-0366.

Gamis, AS. \& Hilden, JM. (2002). Transient myeloproliferative disorder, a disorder with too few data and many unanswered questions: does it contain an important piece of the puzzle to understanding hematopoiesis and acute myelogenous leukemia? Journal of Pediatric Hematology/Oncology: official Journal of the American Society of Pediatric Hematology/Oncology, Vol.24, No.1, (January 2002), pp. 2-5, ISSN 1536-3678.

Gardner, M.; Snee, M.; Hall A. et al.(1990). Results of case control study of leukaemia and lymphoma among young people near Sellafield nuclear plant in West Cumbria. British Medical Journal, Vol.300, No.6722, (February 1990), pp.423-429, ISSN 09598138.

Gillet, N.; Florins, A.; Boxus, M.; Burteau, C.; Nigro, A.; Vandermeers, F.; Balon, H.; Bouzar, AB.; Defoiche, J.; Burny, A.; Reichert, M.; Kettmann, R. \& Willems, L. (2007). Mechanisms of leukemogenesis induced by bovine leukemia virus: prospects for novel anti-retroviral therapies in human. Retrovirology, Vol.4, No.16, (March 2007), pp.18, ISSN 1742-4690.

Glass, A. \& Mantel, N. (1969). Lack of time-space clustering of childhood leukemia in Los Angeles County, 1960-1964. Cancer Research, Vol.29, No.11 (November 1969), pp. 1995-

Greaves, M. \& Chan, L. (1986). Is spontaneous mutation the major "cause" of childhood acute lymphoblastic leukemia. British Journal of Haematology, Vol.64, No.1, (September 1986), pp. 1-13, ISSN 0007-1048.

Greaves, M. (1988). Speculations on the cause of childhood acute lymphoblastic leukaemia. Leukemia, Vol.2, No.2, (February 1988), pp. 120-125, ISSN 0887-6924.

Greaves, M. \& Alexander, F. (1994). Epidemiological characteristics of childhood acute lymphocytic leukemia. Leukemia, Vol.8, No.10, (October 1994), pp.1793-1794, ISSN 0887-6924.

Greaves, M. (2006). Infection, immune responses and the aetiology of childhood leukemia. Nature Reviews Cancer, Vol.6, No.3, (March 2006), pp.93-203, ISSN 1474-1768 
Gross, L. (1951a). Pathogenic properties, and "vertical" transmission of the mouse leukemia agent. Proceedings of the Society for Experimental Biology and Medicine, Vol.78, No.1, (October 1951), pp. 342-348, ISSN 1525-1373.

Gross, L. (1951b) "Spontaneous" leukemia developing in $\mathrm{C} 3 \mathrm{H}$ mice following inoculation in infancy, with AK-leukemic extracts, or AK-embryos. Proceedings of the Society for Experimental Biology and Medicine, Vol.76, No.1, (January 1951), pp. 27-32, ISSN 1525-1373.

Gross, L. (1963) Serial cell-free passage in rats of the mouse leukemia virus. Effect of thymectomy. Proceedings of the Society for Experimental Biology and Medicine, Vol.112, (April 1963), pp. 939-945, ISSN 1525-1373.

Gross, L. (1974). Facts and Theories on Viruses Causing Cancer and Leukemia (Veritical transmission/oncogenic viruses /oncogene theory/protovirus hypotheisis). Proceedings of the National Academy of Sciences of the United States of America, Vol. 71, No.5, pp. 2013-2017, ISSN 0027-8424.

Guise, J.; Austin, D. \& Morris, C. (2005). Review of case-control studies related to breastfeeding and reduced risk of childhood leukemia. Pediatrics, Vol.116, No.5, (November 2005), pp. 724-731, ISSN 1098-4275.

Hasle, H.; Clemmensen, IH. \& Mikkelsen, M. (2000). Risks of leukaemia and solid tumours in individuals with Down's syndrome. Lancet, Vol.355, No.9199, (January 2000), pp. 165-169, ISSN 1474-547X.

Hasle, H. (2001). Pattern of malignant disorders in individuals with Down's syndrome. The Lancet Oncology, Vol.2, No.7, (July 2001), pp. 429-436, ISSN 1470-2045.

Hassold, T.; Abruzzo, M.; Adkins, K.; Griffin, D.; Merrill, M.; Millie, E.; Saker, D.; Shen, J. \& Zaragoza, M. (1996). Human aneuploidy: incidence, origin, and etiology. Environmental and Molecular Mutagenesis, Vol.28, No.3, (1996), pp. 167-175, ISSN 1098-2280.

Heath, C. \& Hasterlik, R. (1990). Leukemia among children in a suburban community 1963. CA: A Cancer Journal for Clinicians, Vol.40, No.1, (Jan-Feb 1990), pp. 27-50, ISSN $1542-4863$.

Hewitt, D. \& Stewart, A. (1951). Measuring the risk of infection at work. British Journal of Social Medicine, Vol.5, No.4, (October 1951), pp. 209-222, ISSN 0366-0842.

Hirayama, T. (1968). [Symposium: Epidemiology of leukemia in Japan. An epidemiological study of leukemia in Japan with special reference to the problem of time-space clustering] [Japanese]. Nippon Ketsueki Gakkai Zasshi, Vol.31, No.5 (October 1968), pp.737-47. ISSN 0001-5806.

Hitzler, JK.; Cheung, J.; Li, Y.; Scherer, SW. \& Zipursky, A. (2003). GATA1 mutations in transient leukemia and acute megakaryoblastic leukemia of Down syndrome. Blood, Vol.101, No.11, (June 2003), pp. 4301-4304, ISSN 1528-0020.

Hitzler, JK. \& Zipursky, A. (2005). Origins of leukaemia in children with Down syndrome. Nature Reviews Cancer, Vol.5, No.1, (January 2005), pp. 11-20, ISSN 1474-1768.

Holland, AJ.; Hon, J.; Huppert, FA. \& Stevens, F. (2000). Incidence and course of dementia in people with Down's syndrome: findings from a population-based study. Journal of Intellectual Disability Research, Vol.44, No.Pt2, (April 2000), pp. 138-146, ISSN 13652788.

Holterman, CE.; Franovic, A.; Payette, J. \& Lee, S. (2010). ETS-1 oncogenic activity mediated by transforming growth factor alpha. Cancer Research, Vol.70, No.2, (January 2010), pp. 730-740, ISSN 1538-7445. 
Huebner, R. \& Todaro, G. (1969). Oncogenes of RNA tumor viruses as determinants of cancer. Proceedings of the National Academy of Sciences of the United States of America, Vol.64, No.3, (November 1969), pp. 1087-1094, ISSN 0027-8424.

Infante, C.; Fortier, I. \& Olson, E. (2000). Markers of infection, breast-feeding and childhood acute leukemia. British Journal of Cancer, Vol.83, No.11, (December 2000), pp.15591564, ISSN 1532-1827.

Ip, S.; Chung, M.; Raman, G.; Chew, P.; Magula, N.; DeVine, D.; Trikalinos, T. \& Lau, J. (2007). Breastfeeding and maternal and infant health outcomes in developed countries. Evidence Report/Technology Assessment, No.153, (April 2007), pp.1-186, ISSN 1530-4396.

Izraeli, S.; Rainis, L.; Hertzberg, L.; Smooha, G. \& Birger, Y. (2007). Trisomy of chromosome 21 in leukemogenesis. Blood Cells, Molecules \& Diseases, Vol.39, No.2, (SeptemberOctober 2007), pp. 156-169, ISSN 1079-9796.

Jarrett, W.; Martin, W.; Crighton, G.; Dalton, R. \& Stewart, M. (1964) Transmission experiments with leukemia (lymphosarcoma). Nature, Vol.202, (May 1964), pp. 566567, ISSN 1476-4687.

Jourdan-Da, N.; Perel, Y.; Méchinaud, F.; Plouvier, E.; Gandemer, V.; Lutz, P.; Vannier, J.; Lamagnére, J.; Margueritte, G.; Boutard, P.; Robert, A.; Armari, C.; Munzer, M.; Millot, F.; De Lumley, L.; Berthou, C.; Rialland, X.; Pautard, B.; Hémon, D. \& Clavel, J. (2004). Infectious diseases in the first year of life, perinatal characteristics and childhood acute leukaemia. British Journal of Cancer, Vol.90, No.1, (January 2004), pp.139-145, ISSN 1532-1827.

Karrman, K.; Forestier, E.; Andersen, MK.; Autio, K.; Borgström, G.; Heim, S.; Heinonen, K.; Hovland, R.; Kerndrup, G. \& Johansson, B; Nordic Society of Paediatric Haematology and Oncology (NOPHO) and the NOPHO Leukaemia Cytogenetic Study Group (NLCSG). (2006). High incidence of the ETV6/RUNX1 fusion gene in paediatric precursor B-cell acute lymphoblastic leukaemias with trisomy 21 as the sole cytogenetic change: a Nordic series of cases diagnosed 1989-2005. British Journal of Haematology, Vol.135, No. 3, (November 2006), pp. 352-354, ISSN 13652141.

Kinlen, L. (1988). Evidence for an infective cause of childhood leukaemia: comparison of a Scottish new town with nuclear reprocessing sites in Britain. Lancet, Vol.2, No.8624, (December 1988), pp. 1323-1327. ISSN 1474-547X.

Kinlen, LJ.; Clarke, K. \& Hudson, C.(1990). Evidence from population mixing in British New Towns 1946-85 of an infective basis for childhood leukaemia. Lancet, Vol. 336, No.8715, (September 1990), pp.557-582, ISSN 1474-547X.

Kwan, L.; Buffler, P.; Abrams, B. \& Kiley, V. (2004). Breastfeeding and the risk of childhood leukemia: a meta-analysis. Public Health Reports, Vol.119, Nov.6, (NovemberDecember 2004), pp.521-535, ISSN 0033-3549.

Levanon, D.; Glusman, G.; Bangsow, T.; Ben-Asher, E.; Male, DA.; Avidan, N.; Bangsow, C.; Hattori, M.; Taylor, TD.; Taudien, S.; Blechschmidt, K; Shimizu, N.; Rosenthal, A.; Sakaki, Y.; Lancet, D. \& Groner Y. Architecture and anatomy of the genomic locus encoding the human leukemia-associated transcription factor RUNX1/AML1. Gene 2001; Vol.262, No.1-2, (January 2001), pp. 23-33, ISSN 0378-1119.

Linabery, AM.; Olshan, AF.; Gamis, AS.; Smith, FO.; Heerema, NA.; Blair, CK. \& Ross JA; Children's Oncology Group. (2006). Exposure to medical test irradiation and acute leukemia among children with Down syndrome: a report from the Children's Oncology Group. Pediatrics, Vol.118, No.5, (November 2006), pp. e1499-e1508, ISSN 1098-4275. 
Linabery, AM.; Blair, CK.; Gamis, AS.; Olshan, AF.; Heerema, NA. \& Ross JA. (2008). Congenital abnormalities and acute leukemia among children with Down syndrome: a Children's Oncology Group study. Cancer Epidemiology, biomarkers $\mathcal{E}$ prevention: a publication of the American Association for Cancer Research, cosponsored by the American Society of Preventive Oncology, Vol.17, No.10, (October 2008), pp. 25722577, ISSN 1538-7755.

Ma, X.; Metayer, C.; Does, M. \& Buffler, P. (2005a). Maternal pregnancy loss, birth characteristics, and childhood leukemia (United States). Cancer Causes \& Control, Vol.16, No.9, (November 2005), pp.1075-1083, ISSN 1573-7225.

Ma, X.; Buffler, P.; Wiemels, J.; Selvin, S.; Metayer, C.; Loh, M.; Does, M. \& Wiencke, J. (2005b). Ethnic difference in daycare attendance, early infections, and risk of childhood acute lymphoblastic leukemia. Cancer Epidemiology, Biomarkers $\mathcal{E}$ Prevention, Vol.14, No.8 (August 2005), pp.1928-1934, ISSN 1538-7755.

Ma, X.; Urayama, K.; Chang, J.; Wiemels, J. \& Buffler, P. (2009). Infection and pediatric acute lymphoblastic leukemia. Blood Cells, Molecules \& Diseases, Vol.42, No.2, (MarchApril 2009), pp.117-120, ISSN 1096-0961.

MacArthur, A.; McBride, M.; Spinelli, J.; Tamaro, S.; Gallagher, R. \& Theriault, G. (2008). Risk of childhood leukemia associated with vaccination, infection, and medication use in childhood: the Cross-Canada Childhood Leukemia Study. American Journal of Epidemiology, Vol.167, No.5, (March 2008), pp.598-606, ISSN 1476-6256.

Macías, S.; Rodríguez, S.; \& Ronayne, P. (2006). Leche materna: composición y factores condicionantes de la lactancia. Archivos Argentinos de Pediatría, Vol.104, No.5, (Septiembre-Octubre 2006), pp.423-430, ISSN 1668-3501.

Malinge, S.; Izraeli, S. \& Crispino, JD. (2009). Insights into the manifestations, outcomes, and mechanisms of leukemogenesis in Down syndrome. Blood, Vol.113, No.12, (March 2009), pp. 2619-2628, ISSN 1528-0020.

Maloney, KW.; Carroll, WL.; Carroll, AJ.; Devidas, M.; Borowitz, MJ.; Martin, PL.; Pullen, J.; Whitlock, JA.; Willman, CL.; Winick, NJ.; Camitta, BM. \& Hunger, SP. (2010). Down syndrome childhood acute lymphoblastic leukemia has a unique spectrum of sentinel cytogenetic lesions that influences treatment outcome: a report from the Children's Oncology Group. Blood, Vol.116, No.7, (August 2010), pp. 1045-1050, ISSN 1528-0020.

McNally, R. \& Eden, T. (2004). An infectious aetiology for childhood acute leukaemia: a review of the evidence. British Journal of Haematology, Vol.127, No.3, (November 2004), pp. 243-263., ISSN 1365-2141.

McNally, R.; Bithell, J.; Vincent, T. \& Murphy, M. (2009). Space-time clustering of childhood cancer around the residence at birth. International Journal of Cancer, Vol.124, No. 2, (January 2009), pp. 449-455, ISSN 1097-0215.

Mejía, JM.; Fajardo, A.; Flores, H.; Martínez, MC.; Salamanca, F.; Palma, V.; Paredes, R.; Bernáldez, R.; Ortiz, A.; Martínez, A. \& Gorodezky, C. (2003). Environmental factors contributing to the development of childhood leukemia in children with Down's syndrome. Leukemia, Vol.17, No.9, (September 2003), pp. 1905-1907, ISSN 1476-5551.

Mejia, JM.; Fajardo, A.; Perez, ML.; Gorodezky, C.; Martinez, A.; Romero, L.; Campo, MA.; Flores, J.; Salamanca, F. \& Velasquez, L. (2007). Magnetic fields and acute leukemia in children with Down syndrome. Epidemiology, Vol.18, No.1, (January 2007), pp. 158-161, ISSN 1531-5487.

Meydan, N.; Grunberger, T.; Dadi, H.; Shahar, M.; Arpaia, E.; Lapidot, Z.; Leeder, JS.; Freedman, M.; Cohen, A.; Gazit, A.; Levitzki, A. \& Roifman, CM. (1996). Inhibition 
of acute lymphoblastic leukaemia by a Jak-2 inhibitor. Nature, Vol.379, No. 6566, (February 1996), pp. 645-648, ISSN 1476-4687.

Migas, A.; Savva, N.; Mishkova, O. \& Aleinikova, OV. (2011). AML1/RUNX1 gene point mutations in childhood myeloid malignancies. Pediatrics Blood and Cancer, DOI: 10.1002/ pbc.22980, (February 2011), ISSN 1545-5017.

Morris, J. (1989). A mutational theory of leukaemogenesis. Journal of Clinical Pathology, Vol.42, No.4, (April 1989), pp.337-340, ISSN 1472-4146.

Mullighan, CG.; Zhang, J.; Harvey, RC.; Collins-Underwood, JR.; Schulman, BA.; Phillips, LA.; Tasian, SK.; Loh, ML.; Su, X.; Liu, W.; Devidas, M.; Atlas, SR.; Chen, IM.; Clifford, RJ.; Gerhard, DS.; Carroll, WL.; Reaman, GH.; Smith, M.; Downing, JR.; Hunger, SP. \& Willman, CL. (2009). JAK mutations in high-risk childhood acute lymphoblastic leukemia. Proceedings of the National Academy Science of the United States of America, Vol.106, No.23, (June 2009), pp. 9414-9418, ISSN 1091-6490.

Neglia, J.; Linet, M.; Shu, X.; Severson, R.; Potter, J.; Mertens, A.; Wen, W.; Kersey, J. \& Robison, L. (2000). Patterns of infection and day care utilization and risk of childhood acute lymphoblastic leukaemia. British Journal of Cancer, Vol.82 No.1, (January 2000), pp.234-240, ISSN 1532-1827.

Ognjanovic, S.; Puumala, S.; Spector, LG.; Smith, FO.; Robison, LL.; Olshan, AF. \& Ross JA. (2009). Maternal health conditions during pregnancy and acute leukemia in children with Down syndrome: A Children's Oncology Group study. Pediatric Blood $\mathcal{E}$ Cancer, Vol.52, No.5, (May 2009), pp. 602-608, ISSN 1545-5017.

Oxford, J.; Manuguerra, C.; Kistner, O.; Linde, A.; Kunze, M.; Lange, W.; Schweiger, B.; Spala, G.; Rebelo de Andrade, H.; Pérez Breña, PR.; Beytout, J.; Brydak, L.; Caraffa de Stefano, D.; Hungnes, O.; Kyncl, J.; Montomoli, E.; Gil de Miguel, A.; Vranckx, R. \& Osterhaus, A. (2005). A new European perspective of influenza pandemic planning with a particular focus on the role of mammalian cell culture vaccines. Vaccine, Vol.23, No.46-47, (November 2005):5440-5449, ISSN 0264-410X.

Parker, L. (2001). Breast-feeding and cancer prevention. European Journal of Cancer, Vol.37, No.2, (January 2001), pp.55-8, ISSN 09-59-8049 81.

Perillat, F.; Clavel, J.; Jaussent, I.; Baruchel, A.; Leverger, G.; Nelken, B.; Philippe, N.; Schaison, G.; Sommelet, D.; Vilmer, E. \& Hemon, D. (2002a). Breast-feeding, fetal loss and childhood acute leukemia. European Journal of Pediatrics, Vol.161, No.4, (April 2002), pp.235-237, ISSN 1432-1076.

Perrillat, F.; Clavel, J.; Auclerc, M.; Baruchel, A.; Leverger, G.; Nelken, B.; Philippe, N.; Schaison, G.; Sommelet, D.; Vilmer, E. \& Hémon, D. (2002b). Day-care, early common infections and childhood acute leukaemia: a multicentre French casecontrol study. British Journal of Cancer, Vol.8, No.86 (April 2002), pp.1064-1069, ISSN 1532-1827.

Petridou, E.; Dalamaga, M.; Mentis, A.; Skalkidou, A.; Moustaki, M.; Karpathios, T.; Trichopoulos, D. \& Childhood Haematologists-Oncologists Group. (2001). Evidence on the infectious etiology of childhood leukemia: the role of low herd immunity (Greece). Cancer Causes \& Control, Vol.12, No.7, (September 2001), pp.645-52, ISSN 1573-7225.

Pinkel, D. \& Nefzger, D. (1959). Some epidemiological features of childhood leukaemia in the Buffalo, NY area. Cancer, Vol.12, No.2, (March-April 2008), pp.351-358, ISSN 1097-0142.

Puumala, SE.; Ross, JA.; Olshan, AF.; Robison, LL.; Smith, FO. \& Spector LG. (2007). Reproductive history, infertility treatment, and the risk of acute leukemia in 
children with down syndrome: a report from the Children's Oncology Group. Cancer, Vol.110, No.9, (November 2007), pp. 2067-2074, ISSN 1097-0142.

Rabson, AB. (2010). Trisomy 21 leukemias: finding the hits that matter. Oncogene, Vol.29, No. 46, (November 2010), pp. 6099-6101, ISSN 1476-5594.

Riveron, R. (1995). Valor inmunológico de la leche materna. Revista Cubana de Pediatría, Vol. 67, No.2, pp.1-16, ISSN 0034-7531.

Robison, LL. (1992). Down syndrome and leukemia. Leukemia, Vol.6, Suppl.1, pp. 5-7, ISSN 1476-5551.

Roman, E.; Simpson, J.; Ansell, P.; Kinsey, S.; Mitchell, C.; McKinney, P.; Birch, J.; Greaves, M.; Eden, T. \& United Kingdom Childhood Cancer Study Investigators. (2007). Childhood acute lymphoblastic leukaemia and infections in the first year of life: A report from the United Kingdom Childhood Cancer Study. American Journal of Epidemiology, Vol.165, No.5, (March 2007), pp.496-504, ISSN 1476-6256.

Rosenbaum, P.; Buck, G. \& Brecher, M. (2000). Early child-care and preschool experiences and the risk of childhood acute lymphoblastic leukemia. American Journal of Epidemiology, Vol.152 No.12, (December 2000), pp.1136-1144, ISSN 1476-6256.

Rosenbaum, P.; Buck, G. \& Brecher, M.; (2005). Allergy and infectious disease histories and the risk of childhood acute lymphoblastic leukaemia. Paediatric and Perinatal Epidemiology, Vol.19, No.2, (March 2005), pp.152-164, ISSN 1365-3016.

Ross, JA. (1999). Epidemiologic studies of childhood leukemia: where do we go from here? Medical and Pediatric Oncology, Vol.32, No.1, (January 1999), pp. 65-67, ISSN 1096911X.

Ross, JA.; Spector, LG.; Robison, LL. \& Olshan, AF. (2005a). Epidemiology of leukemia in children with Down syndrome. Pediatric Blood E Cancer, Vol.44, No.1, (January 2005), pp. 8-12, ISSN 1545-5017.

Ross, JA.; Blair, CK.; Olshan, AF.; Robison, LL.; Smith, FO.; Heerema, NA. \& Roesler, M. (2005b). Periconceptional vitamin use and leukemia risk in children with Down syndrome: a Children's Oncology Group study. Cancer, Vol.104, No.2, (July 2005), pp. 405-410, ISSN 1097-0142.

Roy, A.; Roberts, I.; Norton, A. \& Vyas, P. (2009). Acute megakaryoblastic leukaemia (AMKL) and transient myeloproliferative disorder (TMD) in Down syndrome: a multi-step model of myeloid leukaemogenesis. British Journal of Haematology, Vol.147, No.1, (October 2009), pp. 3-12, ISSN 1365-2141.

Rudant, J.; Orsi, L.; Menegaux, F.; Petit, A.; Baruchel, A.; Bertrand, Y.; Lambilliotte, A.; Robert, A.; Michel, G.; Margueritte, G.; Tandonnet, J.; Mechinaud, F.; Bordigoni, P.; Hémon, D. \& Clavel, J. (2010). Childhood acute leukemia, early common infections, and allergy: The ESCALE Study. American Journal of Epidemiology, Vol.172, No.9, (November 2010), pp.1015-1027, ISSN 1476-6256.

Sashida, G.; Bazzoli, E.; Menendez, S.; Liu, Y. \& Nimer, SD. The oncogenic role of the ETS transcription factors MEF and ERG. Cell Cycle, Vol.9, No. 17, (September 2010), pp. 3457-3459, ISSN 1551-4005.

Schüz, J.; Kaletsch, U.; Meinert, R.; Kaatsch, P. \& Michaelis, J. (1999). Association of childhood leukaemia with factors related to the immune system. British Journal of Cancer, Vol.80, No.3-4, (May 1999), pp.585-90, ISSN 1532-1827.

Shu, X.; Clemens, J.; Zheng, W.; Ying, D.; Ji, B. \& Jin, F. (1995). Infant breastfeeding and the risk of childhood lymphoma and leukaemia. International Journal of Epidemiology, Vol.24, No.1, (February 1995), pp. 27-32, ISSN 1464-3685 83.

Shu, X.; Linet, M.; Steinbuch, M.; Wen, W.; Buckley, J.; Neglia, J.; Potter, J.; Reaman, G. \& Robison, L. (1999). Breast-feeding and risk of childhood acute leukemia. Journal 
National Cancer Institute, Vol.91, No.20, (October 1999), pp.1765-1772, ISSN 1460210577.

Speck, NA. \& Gilliland, DG. (2002). Core-binding factors in haematopoiesis and leukaemia. Nature Reviews Cancer, Vol.2, No.7, (July 2002), pp. 502-513, ISSN 1474-1768.

Stuebe, A. (2009). The risks of not breastfeeding for mothers and infants. Reviews in Obstetrics and Gynecology, Vol.2 No.4, (Fall 2009), pp.222-231, ISSN 1941-2797.

Taub, JW. (2001). Relationship of chromosome 21 and acute leukemia in children with Down syndrome. Journal of Pediatric Hematology/Oncology, Vol.23, No.3, (March-April 2001), pp. 175-178, ISSN 1536-3678.

Taub, JW. \& Ravindranath, Y. (2002). Down syndrome and the transient myeloproliferative disorder: why is it transient? Journal of Pediatric Hematology/Oncology: official Journal of the American Society of Pediatric Hematology/Oncology, Vol.24, No.1, (January 2002), pp. 6-8, ISSN 1536-3678.

Todaro, GJ. \& Huebner, RJ. (1972) N.A.S. symposium: new evidence as the basis for increased efforts in cancer research. Proceedings of the National Academy of Sciences of the United States of America, Vol.69, No.4, (April 1972), pp. 1009-1015, ISSN 00278424 .

Urayama, K.; Buffler, P.; Gallagher, E.; Ayoob, J.; Ma, X. (2010). A meta-analysis of the association between day-care attendance and childhood acute lymphoblastic leukaemia. International Journal of Epidemiology, Vol.39, No.3 (June 2010), pp.718732, ISSN 1464-3685 64.

Urayama, K.; Ma, X.; Selvin, S.; Metayer, C.; Chokkalingam, A.; Wiemels, J.; Does, M.; Chang, J.; Wong, A.; Trachtenberg, E. \& Buffler, P. (2011). Early life exposure to infections and risk of childhood acute lymphoblastic leukemia. International Journal of Cancer, Vol.128, No.7, (April 2011), pp.632-643, ISSN 1811-9735.

Van Cleve, SN. \& Cohen, WI. (2006). Part I: clinical practice guidelines for children with Down syndrome from birth to 12 years. Journal of Pediatric Health Care: official publication of National Association of Pediatric Nurse Associates EPractitioners, Vol.20, No.1, (January-February 2006), pp. 47-54, ISSN 0891-5245.

van Steensel, H.; Valkenburg; H. \& van Zanen G. (1986). Childhood leukemia and infectious diseases in the first year of life: a register-based case-control study. American Journal of Epidemiology, Vol.124 No.4, (October 1986), pp.590-594, ISSN 1476-6256.

Vyas, P. \& Roberts, I. (2006). Down myeloid disorders: a paradigm for childhood preleukaemia and leukaemia and insights into normal megakaryopoiesis. Early Human Development, Vol.82, No.12, (December 2006), pp. 767-773, ISSN 0378-3782.

Wahab, AA.; Bener, A. \& Teebi, AS. (2006). Clinical Genetics, Vol.69, No.4, (April 2006), pp. 360-362, ISSN 0009-9163.

Webb, D.; Roberts, I. \& Vyas, P. (2007). Haematology of Down syndrome. Archives of Disease in Childhood Fetal and Neonatal Edition, Vol.92, No.6, (November 2007), pp. F503F507, ISSN 1468-2052.

Wechsler, J.; Greene, M.; McDevitt, MA.; Anastasi, J.; Karp, JE.; Le Beau, MM. \& Crispino, JD. (2002). Acquired mutations in GATA1 in the megakaryoblastic leukemia of Down syndrome. Nature Genetics, Vol.32, No. 1, (September 2002), pp. 148-152, ISSN 1546-1718.

Wiseman, FK.; Alford, KA.; Tybulewicz, VL. \& Fisher, EM. (2009). Down syndrome-recent progress and future prospects. Human Molecular Genetics, Vol.18, No.R1 (April 2009), pp.R75-R83, ISSN 1460-2083.

Xavier, AC. \& Taub, JW. (2010). Acute leukemia in children with Down syndrome. Haematologica, Vol.95, No.7, (July 2010), pp. 1043-1045, ISSN 1592-8721. 
Zipursky, A. (2003). Transient leukaemia--a benign form of leukaemia in newborn infants with trisomy 21. British Journal of Haematology, Vol.120, No.6, (March 2003), pp. 930938, ISSN 1365-2141.

Zuna, J.; Madzo, J.; Krejci, O.; Zemanova, Z.; Kalinova, M.; Muzikova, K.; Zapotocky, M.; Starkova, J.; Hrusak, O.; Horak, J. \& Trka, J. (2011). ETV6/RUNX1 (TEL/AML1) is a frequent prenatal first hit in childhood leukemia. Blood, Vol.117, No.1, (January 2011), pp. 368-369, ISSN 1528-0020.

Zwaan, CM.; Reinhardt, D.; Hitzler, J. \& Vyas, P. (2010). Acute leukemias in children with Down syndrome. Hematology/Oncology Clinics of North America, Vol.24, No.1, (February 2010), pp. 19-34, ISSN 0889-8588. 


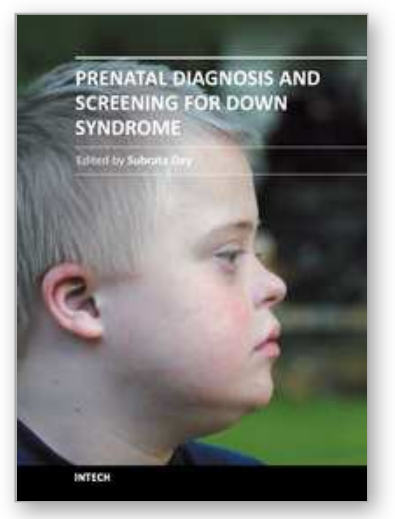

\author{
Prenatal Diagnosis and Screening for Down Syndrome \\ Edited by Prof. Subrata Dey
}

ISBN 978-953-307-355-2

Hard cover, 232 pages

Publisher InTech

Published online 17, August, 2011

Published in print edition August, 2011

This book provides a concise yet comprehensive source of current information on Down syndrome. Research workers, scientists, medical graduates and paediatricians will find it an excellent source for reference and review. This book focuses on exciting areas of research on prenatal diagnosis - Down syndrome screening after assisted reproduction techniques, noninvasive techniques, genetic counselling and ethical issues. Whilst aimed primarily at research worker on Down syndrome, we hope that the appeal of this book will extend beyond the narrow confines of academic interest and be of interest to a wider audience, especially parents and relatives of Down syndrome patients.

\title{
How to reference
}

In order to correctly reference this scholarly work, feel free to copy and paste the following:

Juan Manuel Mejia-Aranguré, Maria Luisa Pérez-Saldivar, Janet Flores-Lujano, Carolina Bekker Méndez, Sandra Pinto-Cardoso, David Aldebarán Duarte-Rodriguez and Arturo Fajardo-Gutiérrez (2011). Infections and Acute Leukemia in Children with Down Syndrome, Prenatal Diagnosis and Screening for Down Syndrome, Prof. Subrata Dey (Ed.), ISBN: 978-953-307-355-2, InTech, Available from:

http://www.intechopen.com/books/prenatal-diagnosis-and-screening-for-down-syndrome/infections-and-acuteleukemia-in-children-with-down-syndrome

\section{INTECH}

open science | open minds

\author{
InTech Europe \\ University Campus STeP Ri \\ Slavka Krautzeka 83/A \\ 51000 Rijeka, Croatia \\ Phone: +385 (51) 770447 \\ Fax: +385 (51) 686166 \\ www.intechopen.com
}

\author{
InTech China \\ Unit 405, Office Block, Hotel Equatorial Shanghai \\ No.65, Yan An Road (West), Shanghai, 200040, China \\ 中国上海市延安西路65号上海国际贵都大饭店办公楼 405 单元 \\ Phone: +86-21-62489820 \\ Fax: +86-21-62489821
}


(C) 2011 The Author(s). Licensee IntechOpen. This chapter is distributed under the terms of the Creative Commons Attribution-NonCommercialShareAlike-3.0 License, which permits use, distribution and reproduction for non-commercial purposes, provided the original is properly cited and derivative works building on this content are distributed under the same license. 